by Claudia Agnini', Jan Backman 2, Flavia Boscolo-Galazzo 3 , Daniel J. Condon 4 , Eliana Fornacia$\mathrm{ri}^{1}$, Simone Galeotti ${ }^{5,16}$, Luca Giusberti ${ }^{1}$, Paolo Grandesso ${ }^{1}$, Luca Lanci ${ }^{5,16}$, Valeria Luciani ${ }^{6}$, Simonetta Monechi ${ }^{7}$, Giovanni Muttoni ${ }^{8}$, Heiko Pälike ${ }^{9}$, Maria Letizia Pampaloni ${ }^{10}$, Cesare A. Papazzoni ${ }^{11}$, Paul N. Pearson ${ }^{3}$, Johannes Pignatti ${ }^{2}$, Isabella Premoli Silva ${ }^{8}$, Isabella Raffi ${ }^{13}$, Domenico Rio ${ }^{1}$, Lorenzo Rook ${ }^{7}$, Diana Sahy ${ }^{4}$, David J.A. Spofforth ${ }^{14}$, Cristina Stefani ${ }^{1}$, and Bridget S. Wade ${ }^{15}$

\title{
Proposal for the Global Boundary Stratotype Section and Point (GSSP) for the Priabonian Stage (Eocene) at the Alano section (Italy)
}

\author{
${ }^{1}$ Dipartimento di Geoscienze, Università di Padova, Padova, Italy; *Corresponding author, E-mail: claudia.agnini@unipd.it \\ ${ }^{2}$ Department of Geological Sciences, Stockholm University, Stockholm, Sweden \\ ${ }^{3}$ School of Earth and Ocean Sciences, Cardiff University, Cardiff, United Kingdom \\ ${ }^{4}$ British Geological Survey, Keyworth, Nottingham, United Kingdom \\ ${ }^{5}$ Dipartimento di Scienze Pure e Applicate, Università di Urbino Carlo Bo, Urbino, Italy \\ ${ }^{6}$ Dipartimento di Fisica e Scienze della Terra, Università di Ferrara, Ferrara, Italy \\ ${ }^{7}$ Dipartimento di Scienze della Terra, Università di Firenze, Firenze, Italy \\ ${ }^{8}$ Dipartimento di Scienze della Terra "Ardito Desio", Università di Milano, Milano, Italy \\ ${ }^{9}$ Marum, University of Bremen, Bremen, Germany \\ ${ }^{10}$ Istituto Superiore per la Protezione e la Ricerca Ambientale (ISPRA), Roma, Italy \\ ${ }^{11}$ Dipartimento di Scienze Chimiche e Geologiche, Università di Modena e Reggio Emilia, Modena, Italy \\ ${ }^{12}$ Dipartimento di Scienze della Terra, Università La Sapienza, Roma, Italy \\ ${ }^{13}$ Dipartimento di Ingegneria e Geologia, Università "G. d'Annunzio", Chieti-Pescara, Italy \\ ${ }^{14}$ CGG MCNV (GeoSpec), Llandudno, United Kingdom \\ ${ }^{15}$ Department of Earth Sciences, University College of London, London, United Kingdom \\ ${ }^{16}$ Institute for Climate Change Solutions, Pesaro e Urbino, Italy
}

(Received: July 31, 2020; Revised accepted: August 12, 2020)

https://doi.org/10.18814/epiiugs/2020/020074

The base of the Priabonian Stage is one of two stage boundaries in the Paleogene that remains to be formalized. The Alano section (NE Italy) was elected by consensus as a suitable candidate for the base of the Priabonian during the Priabonian Working Group meeting held in Alano di Piave in June 2012. Further detailed research on the section is now followed by a formal proposal, which identifies the base of a prominent crystal tuff layer, the Tiziano bed, at meter 63.57 of the Alano section, as a suitable candidate for the Priabonian Stage. The choice of the Tiziano bed is appropriate from the historical point of view and several bio-magnetostratigraphic events are available to approximate this chronostratigraphic boundary and guarantee a high degree of correlatability over wide geographic areas. Events which approximate the base of the Priabonian Stage in the Alano section are the successive extinction of large acarininids and Morozovelloides (planktonic foraminifera), the Base of common and continuous Cribrocentrum erbae and the Top of Chiasmolithus grandis (nannofossils), as well as the Base of Subchron C17n.2n and the Base of
Chron C17n (magnetostratigraphy). Cyclostratigraphic analysis of the Bartonian-Priabonian transition of the Alano section as well as radioisotopic data of the Tiziano tuff layer provide an absolute age (37.710 - 37.762 Ma, respectively) of this bed and, consequently, of the base of the Priabonian Stage.

\section{Introduction}

According to the guidelines of the International Commission on Stratigraphy (ICS), stages should be defined by their lower boundary, which is identified in a specific stratigraphic layer in a reference section, the Global Stratotype Section and Point (GSSP). This implies that a GSSP has to be defined in a sedimentary succession where sedimentation is continuous and expanded across the boundary interval (Remane et al., 1996; Remane, 2003). The ICS revised guidelines (Remane et al., 1996) also recommend that a section proposed as a candidate for a GSSP has to comply with a series of requirements in order to be suitable to give the best documentation of marker events occurring across the boundary transition. The perfect section should 
thus meet a set of requirements regarding general geology (good exposure over an adequate thickness, continuous sedimentation, adequate sedimentation rate, absence of synsedimentary and tectonic disturbances, absence of metamorphism and strong diagenetic alteration), biostratigraphy (abundance and diversity of well-preserved fossils, absence of vertical facies changes, favorable facies for long-range biostratigraphic correlation) and other non-biostratigraphic characteristics (radioisotopic data, magnetostratigraphy, chemostratigraphy). A new GSSP should be identified, permanently, within the section (i.e., the golden spike) which should be freely accessible with long-lasting protection of the site.

Once a candidate section for a GSSP has been recognized, as is the case of the Priabonian, what still remains to be done is to define the GSSP level. The ICS guidelines recommend that "The boundary definition will normally start from the identification of a level which can be characterised by a marker event of optimal correlation potential. This marker event may be a magnetic reversal, some kind of geochemical or isotopic signal, or the first appearance or last occurrence of a fossil species. However, only the boundary point in the section, the GSSP (Cowie et al., 1986) formally defines the boundary. This means that an occurrence of the primary marker does not automatically determine the boundary. Other markers should therefore be available near the critical level, in order to support chronostratigraphic correlation in sections other than the GSSP" (p. 79 in Remane et al., 1996).

This clarifies that the boundary level and the primary stratigraphic marker are different concepts; once a boundary level in the stratotype has been formally defined and ratified it is generally identified by a physical marker ('golden spike') to which all other stratigraphic sections should be correlated with whatever means are available. Golden spikes are special locations in the global rock succession that define the base of chronostratigraphic units (within the rock sequence) for alignment with geochronologic units (time). Stratigraphers are mindful of the fact that even the best stratigraphic marker is neither omnipresent nor perfectly synchronous so the primary marker becomes just one of various tools that may support accurate correlation from the GSSP to any other section of interest. The recommendation that a GSSP should contain multiple events close to the boundary level has been a guiding principle in our search for the best boundary level along with other desirable characteristics, such as that the chosen level should try to respect historical usage as far as possible and the desirability of geological materials that can be directly dated (Remane et al., 1996).

\section{The Priabonian Stage: historical background}

The Priabonian Stage is named after the village of Priabona, which is located in the eastern Lessini Mountains of northeastern Italy. The stage was proposed by Munier-Chalmas and de Lapparent in deLapparent (1893, p. 1219) and later reiterated by Munier-Chalmasand de Lapparent (1894, p. 479), on the basis of documentation available from a number of sedimentary successions of the Lessini Shelf area. Subsequently, much effort has been made to overcome serious problems encountered in correlating middle-upper Eocene marine stratigraphic records across Europe and the Mediterranean. Among the different sections indicated by Munier-Chalmas and de Lapparent (1894), the Priabona section was formally proposed by Hardenbol (1968) as the stratotype section of the Priabonian. This proposal was accepted at the Eocene Colloquium held in Paris in 1968, at which time a suite of five parastratotype (= auxiliary stratotype; Cowie et al., 1986) sections was also proposed (Cita, 1969), namely the Granella and Ghenderle (or Val Bressana) sections in the Lessini Mountains, the Brendola and Mossano sections in the Berici Hills, and the Possagno section in the Venetian Prealps. The sections in the Lessini Mountains (Priabona, Granella and Ghenderle) are located close to the margin of a carbonate platform (the Lessini Shelf; Bosellini, 1989) connected to the north with emergent land. Their content in calcareous plankton is poor, which makes precise correlation difficult to establish (Verhallen and Romein, 1983). The sections in the Berici Hills (Brendola and Mossano sections) were deposited on the Lessini Shelf although in a more distal position compared to the Lessini Mountains sections. Despite that, calcareous plankton are also scarce in the section (Luciani et al., 2002). The last and most promising auxiliary stratotype section is at Possagno; this succession was deposited on the gentle ramp between the Lessini Shelf and the Belluno Trough. Because of its deeper depositional setting it is characterized by abundant calcareous plankton which has allowed the construction of a consistent biochronostratigraphic framework (Bolli, 1975; Agnini et al., 2006).

\section{Traditional Paleontological Criteria for Recognizing the Base of the Priabonian Stage}

In shallow-water sections, the Base (B) of Nummulites fabianii, which defines the Base of Shallow Benthic foraminiferal Zone SB19 (Serra-Kiel et al., 1998) has been the master paleontological criterion for recognizing the Priabonian Stage. The Base of $N$. fabianii has been recognized in the Priabona and Mossano sections (Hottinger, 1977; Parisi et al., 1988; Bassi and Loriga Broglio, 1999; Bassi et al., 2000) as well as in several other Tethyan shallow-water successions (e.g., Strougo, 1992; Serra-Kiel et al., 1998).

In deep-water sections, where calcareous plankton fauna and flora are usually more abundant, the base of the Priabonian Stage has been traditionally recognized either by the extinction of the muricate planktonic foraminifera Morozovelloides and large acarininids, which coincide with the Base of Zone E14 (Berggren and Pearson, 2005; Wade et al., 2011), or with the Base of the nannofossil Chiasmolithus oamaruensis, which defines the Base of Zone NP18 (Martini, 1971). A virtual correspondence between the Base of $N$. fabianii (Base of Zone SB 19) and the Base of $C$. oamaruensis (Base of Zone NP18) was for a long time generally accepted (Serra-Kiel et al., 1998). However, data from the northern Mediterranean area indicate that the Base of $N$. fabianii there lies at a higher correlative level, namely in the upper part of Zone NP18 or middle part of Zone E14 (Papazzoni and Sirotti, 1995). More recently, a number of new records have confirmed that the Base of Zone SB19 is much higher than the calcareous plankton biohorizons that have been used to approximate the base of the Priabonian (i.e., the Top of large acarininids and Morozovelloides, the Base of $C$. oamaruensis, the $\mathrm{Bc}$ (Base of continuous and common) of $C$. erbae and the Top of C. grandis; Papazzoni et al., 2014; Cotton et al., 2017; Rodelli et al., 2018; Luciani et al., 2020). Specifically, the Base of Zone SB19 is now thought to be close to the CNE18-19 zonal boundary and lies in the lowermost part of Zone E15 (Cotton et al., 2017). The corresponding difference in time between potential Priabonian marker horizons is significant, potentially over two million years. 


\section{Position of the Priabonian Stage in the Eocene Series}

In their overview of the Paleogene System/Period Luterbacher et al. (2004) still used the lower/early, middle and upper/late subdivision for the Eocene Series/Epoch, but the most recent version of the Geological Time Scale (Vandenberghe et al., 2012) as well as the official International Chronostratigraphic Chart edited by ICS (http://www. stratigraphy.org/index.php/ics-chart-timescale) does not use sub-series/ sub epoch (lower/early, middle and upper/late) as formal subdivisions for the Eocene (see Pearson et al., 2017 for a review). We thus refrain from using these terms in a formal sense. The history of the chronostratigraphic subdivision of the Eocene is complicated (e.g., Berggren et al., 1985, 1995; Luterbacher et al., 2004; Vandenberghe et al., 2012). As argued by Berggren et al. (1995), the problem with the placement of the base of the Priabonian has been intimately linked with the difficulties in correlating the classical NW Europe sections, located in the Paris and London basins, with those cropping out in the Veneto region of the Mediterranean area (Munier-Chalmas and de Lapparent, 1894).

\section{Current Practice in Recognizing the base of the Priabonian}

Over the past three decades, the compilations published by Berggren and co-workers $(1985,1995)$ have represented a fundamental reference for the entire community of marine and continental stratigraphers. Berggren et al. (1985) carefully reviewed the status of the Bartonian/Priabonian boundary, which they placed at the Base of $C$. oamaruensis (calcareous nannofossil Zone NP18) founded on the best correlation tools available at that time. According to this concept, the base of the Priabonian correlates with the younger part of Chron C17n (Fig. 4 in Berggren et al., 1985). Berggren et al. (1995) indicated that the Bartonian/Priabonian boundary is correlative with the Base of $C$. oamaruensis, that is the Base of Zone NP18, for which they provided a revised estimated age of 37.0 Ma (Fig. 2 in Berggren et al., 1995). Since 1995 a considerable amount of new research has been conducted on the calcareous plankton biostratigraphy and biochronology of the interval (Wade, 2004; Fornaciari et al., 2010; Wade et al., 2011; 2012; Agnini et al., 2011; 2014). Agnini et al. (2011) demonstrated that the Base of C. oamaruensis (Base of Zone NP18), although poorly reproducible (Fornaciari et al., 2010), is much closer to the successive extinctions of large muricate planktonic foraminifera than previously thought. Most importantly, the Top of large acarininids and Morozovelloides are consistently found to occur closely spaced (+ $85 \mathrm{kyr}$ and $2 \mathrm{kyr}$, respectively) relative to the Top of $C$. grandis (Base of Subzone CP15a of Okada and Bukry, 1980) and the Base of common and continuous C. erbae (Base of Zone CNE17 of Agnini et al., 2014). All these new data are of considerable importance to constrain the critical interval in which the Priabonian GSSP should be defined.

\section{Possible Markers for Identifying the Priabonian GSSP}

According to the historical overview briefly discussed above, the base of the Priabonian in marine stratigraphic records has been identified using the following events:

1) the Base of Nummulites fabianii, by definition the Base of Zone SB19, applied in shallow water facies (e.g., Serra-Kiel, 1998);

2) the Top of large muricate planktonic foraminifera (large acarini- nids and Morozovelloides), coinciding with the Base of Zone E14 (Wade et al., 2011) which is defined by the Top of Morozovelloides crassatus.

3) the Base of Chiasmolithus oamaruensis, Base of Zone NP18, (e.g., Berggren et al., 1985, 1995), which is consistently found close to the Top of $C$. grandis and the Base of common and continuous C. erbae.

4) The Base of Subchron C17n.1n, as proposed by Berggren et al. $(1985,1995)$ and provisionally suggested for practical reasons by Vandenberghe et al. (2012; GTS2012).

All the aforementioned events, with the exception of the Base of $N$. fabianii which is now demonstrated to lie well above the current use of Priabonian, fall relatively close one to each other. It was thus concluded that the Priabonian GSSP should be defined across an interval in which these events occur, which extends from the Base of Subchron C17n.3n to the Base of Subchron C17n.1n.

\section{Selecting the area of the Priabonian GSSP: the Alano section}

The time frame of the Priabona section regarded as "stratotypic" by Hardenbol (1968) is controversial because of the shallow-water transgressive nature of the basal portion of the succession (Setiawan, 1983). The base of the section appears to be younger than the base of the Priabonian stage according to current practices of recognition (e.g., Setiawan, 1983; Brinkhuis, 1994). Specifically, the common and continuous occurrence of Isthmolithus recurvus is widely used as an intra-Priabonian biohorizon defining the Base of Zone NP19 and Subzone CP15b (Fornaciari et al., 2010; Agnini et al., 2011). This biohorizon is documented from the base of the Priabona section suggesting that, at least the lower part of the 'Priabonian', as currently understood (see discussion above), is missing in the Priabona section (Verhallen and Romein, 1983). Among the five parastratotypes proposed by Cita (1969) for the Priabonian, the Granella, Ghenderle, Brendola and Mossano sections are unsuitable for defining a chronostratigraphic unit because of the scarcity of calcareous plankton and/or major facies changes (e.g., Luciani et al., 2002). The deep-water Possagno section was potentially more suitable. Previous studies performed in the 1970s have provided a solid framework based on calcareous plankton biostratigraphy (Bolli, 1975) but unfortunately the critical transition from the Bartonian to the Priabonian is poorly exposed, and no compelling candidacy of the Priabonian GSSP could be thus advanced for this section (Agnini et al., 2011). More suitable to define the base of the Priabonian would be a section that is stratigraphically more continuous and well exposed with marker events that are well constrained in time and suitable for global correlation. The Alano section, located $\sim 50 \mathrm{~km}$ to the NE of the historical Priabona section, meets all the requirements for serving as suitable Priabonian GSSP (Figs. 1-2).

This sedimentary succession, consisting of $\sim 120 \mathrm{~m}$ of hemipelagic marls, is easy to access, crops out continuously, is unaffected by any invasive structural deformation, is rich in calcareous plankton, is provided with magnetic minerals that carry a primary magnetostratigraphic signal, and in general contains an expanded and complete record of the critical interval for defining the GSSP of the Priabonian (Agnini et al., 2011; Fig. 3). The integrated, highly-resolved bio-magnetostratigraphic framework provided for the Alano section (Agnini et al., 2011) 

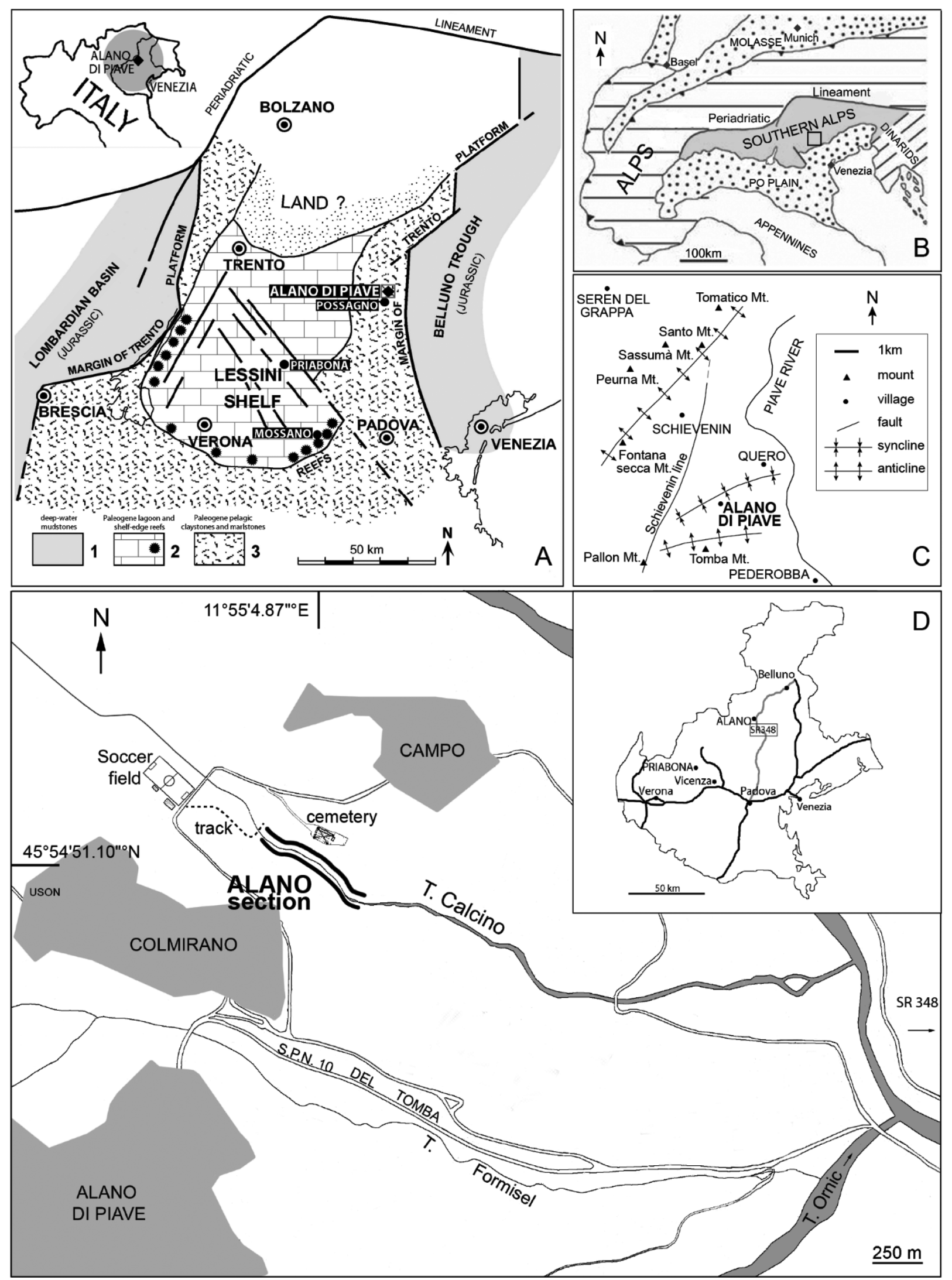

Figure 1. (modified after Agnini et al., 2011). Geographic and geological context of the Alano section. (A) Paleogeographic reconstruction of the main paleogeographic elements of the southern Alps during the Paleogene (adapted from Bosellini and Papazzoni, 2003). (B) the Southern Alps, a major structural subdivision of the Alpine chain, located to the south of the Periadriatic lineament; $\square=$ Studied areas (adapted from Doglioni and Bosellini, 1987). (C) Simplified structural sketch of the study area; $\square$ Grey square in (A) includes the structural map provided. (D) Location map of the study area with indication of the Alano section. The easiest access to the section (dashed line) is shown. 


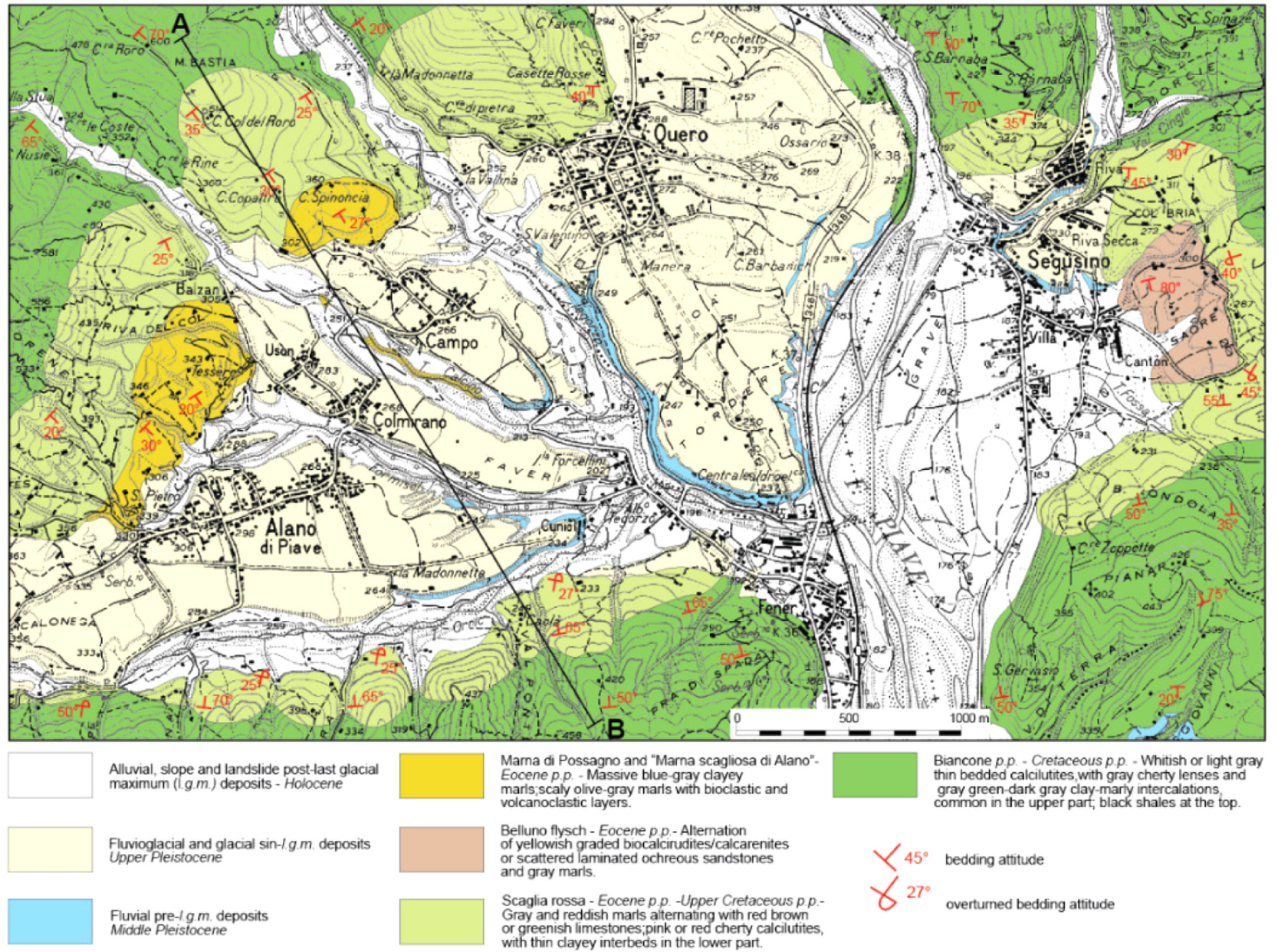

Figure 2. (modified after Agnini et al., 2011). Geological map of the study area. A legend with a detailed description of lithostratigraphic units is also reported in the lower part of the figure.

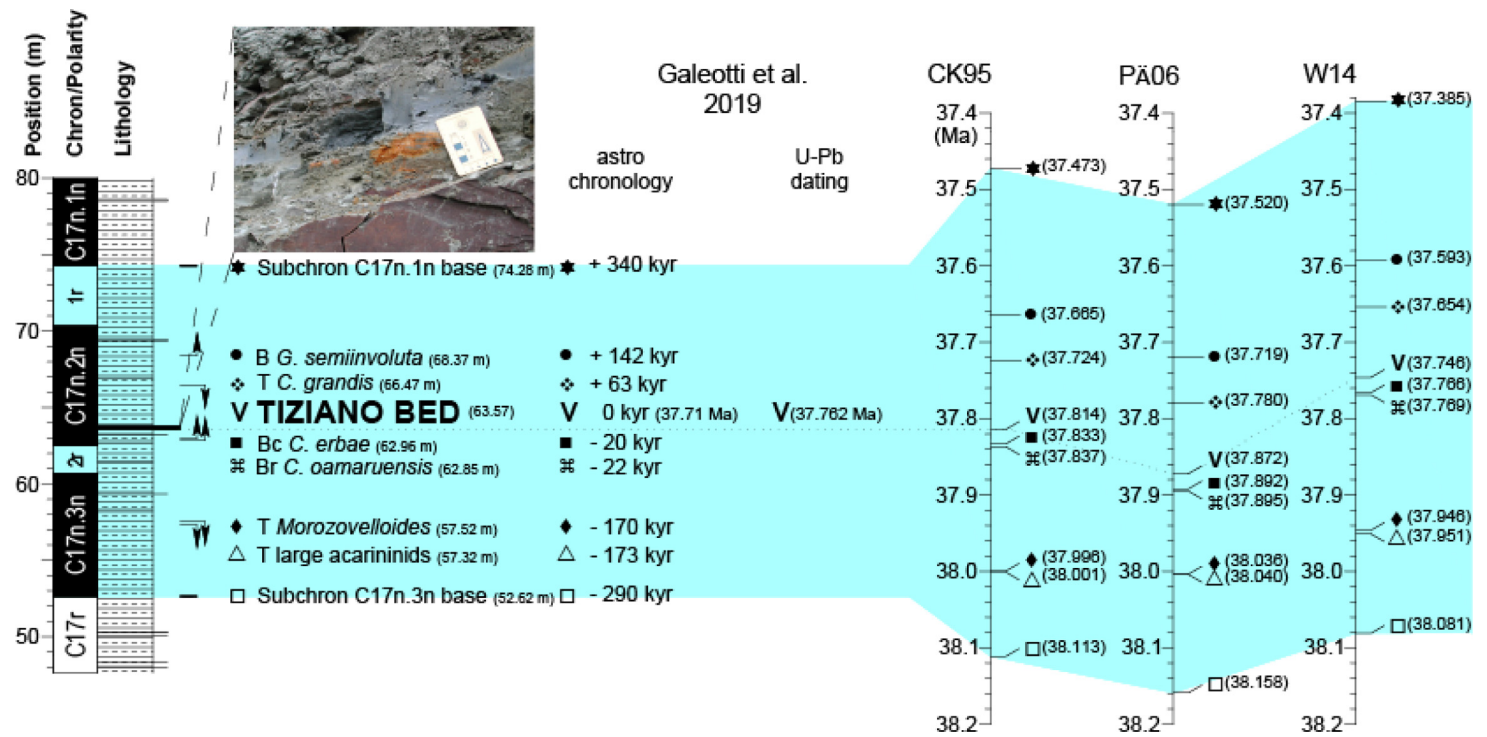

Figure 3. (modified after Agnini et al., 2011). Close-up of the critical interval for defining the base of the Priabonian. Bio-magnetostratigraphic events considered as useful for approximating the Bartonian/Priabonian boundary, that is the base of the Tiziano bed (picture up left in the figure), are plotted against magnetostratigraphy and lithology. Age estimations for the Tiziano bed as well as for biomagnetostratigraphic events are calculated using different time scales (CK95, Cande and Kent 1995; PÄ06, Pälike et al., 2006; W14, Westerhold et al., 2014) and are reported on the right side. Br-Base rare; Bc-Base common and continuous; T-Top. The light blue shaded band identifies the BartonianPriabonian transition, the critical interval where the Priabonian GSSP should be defined. $\star=S u b c h r o n$ C17n.1n base; $\mathbf{O}=$ Base Globigerinatheka semiinvoluta; $*$ Top Chiasmolithus grandis; $V=$ Tiziano bed; $\square=$ Base common and continous Cribrocentrum erbae; $\mathscr{H}=$ Base rare (Br) Chiasmolithus oamaruensis; $\$$ = Top Morozovelloides; $\triangle=$ Top large acarininids; $\square=$ Subchron C17n.3n base. 


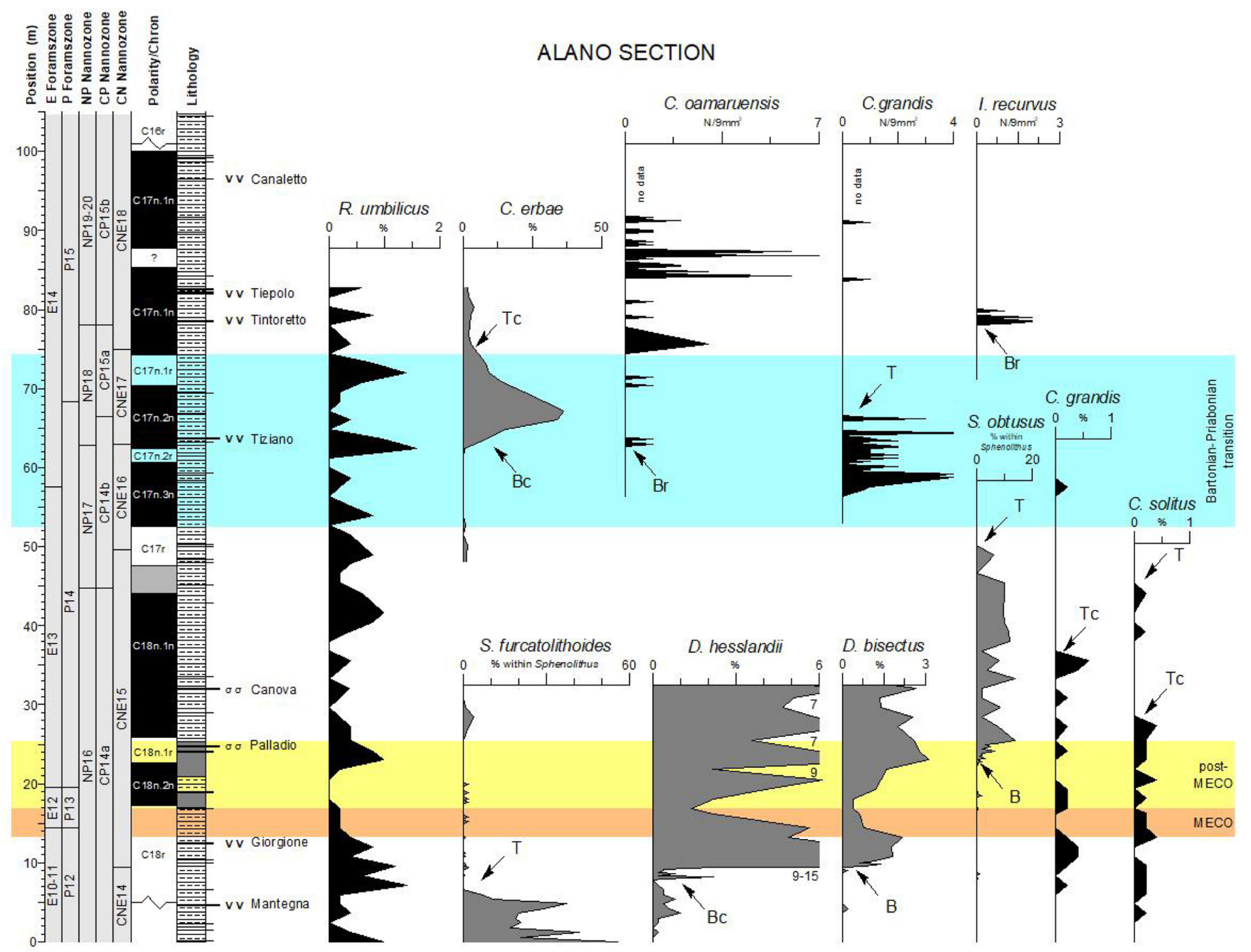

Figure 4. (modified after Agnini et al. 2011). Quantitative distribution patterns of selected calcareous nannofossils and resulting biostratigraphic classification of the Alano section according to the zonal schemes of Martini (NP; 1971), Okada and Bukry (CP; 1980) and Agnini et al., (CN; 2014). Planktonic foraminiferal biozonations are after Berggren et al. (P zones; 1995) and Berggren and Pearson (2005) or Wade et al., 2011 (E zones). The positions of the crucial biohorizons in the Bartonian-Priabonian transition is reported in Table 1. Br-Base rare; BBase; Bc-Base common and continuous; Tc-Top common; T-Top. The shaded orange band indicates the MECO, the shaded yellow band marks the post-MECO interval and the light blue shaded band identifies the Bartonian-Priabonian transition, the critical interval where the Priabonian GSSP should be defined.

can be used as a starting reference record to strengthen the traceability potential of some of the marker events outside the local depositional basin.

To investigate the wider correlation potential, calcareous plankton data available for the Alano section (Figs. 4-5) were compared with data acquired at ODP Site 1052 (western North Atlantic; Fig. 6). This exercise showed that the successive extinction of large acarininids and Morozovelloides occurred consistently in the middle part of Chron C17n.3n (Wade, 2004; Agnini et al., 2011). Wade et al. (2012) emphasized the desirable features of these closely spaced and easily recognized extinction events for global correlation in low and mid latitudes, providing corroborating evidence for their robustness and synchrony across the Atlantic Ocean.

The same approach was performed for calcareous nannoplankton and permits constraint of the relative timing among some calcareous nannofossil biohorizons and their relationship with planktonic foraminiferal bioevents (Fig. 3). The Base of $C$. oamaruensis, one of the traditional events used to approximate the base of the Priabonian, occurs at the Base of Subchron C17n.2n, but its reproducibility is generally considered very poor (Fornaciari et al., 2010; Agnini et al., 2011). Nevertheless, the highly resolved biostratigraphic dataset available for the studied section pointed out two further biohorizons: the Base of common and continuous C. erbae, marking the Base of Zone CNE17 (Fig. 4; Agnini et al., 2014) and the Top of C. grandis, defining the Base of Subzone CP15b (Okada and Bukry, 1980). These two closely spaced biohorizons are consistently found within Subchron C17n.2n in the proximity to the Base of $C$. oamaruensis (Fornaciari et al., 2010; Agnini et al., 2011, 2014).

In summary, calcareous plankton (i.e., planktonic foraminifera and calcareous nannofossils) provide an excellent series of biohorizons 


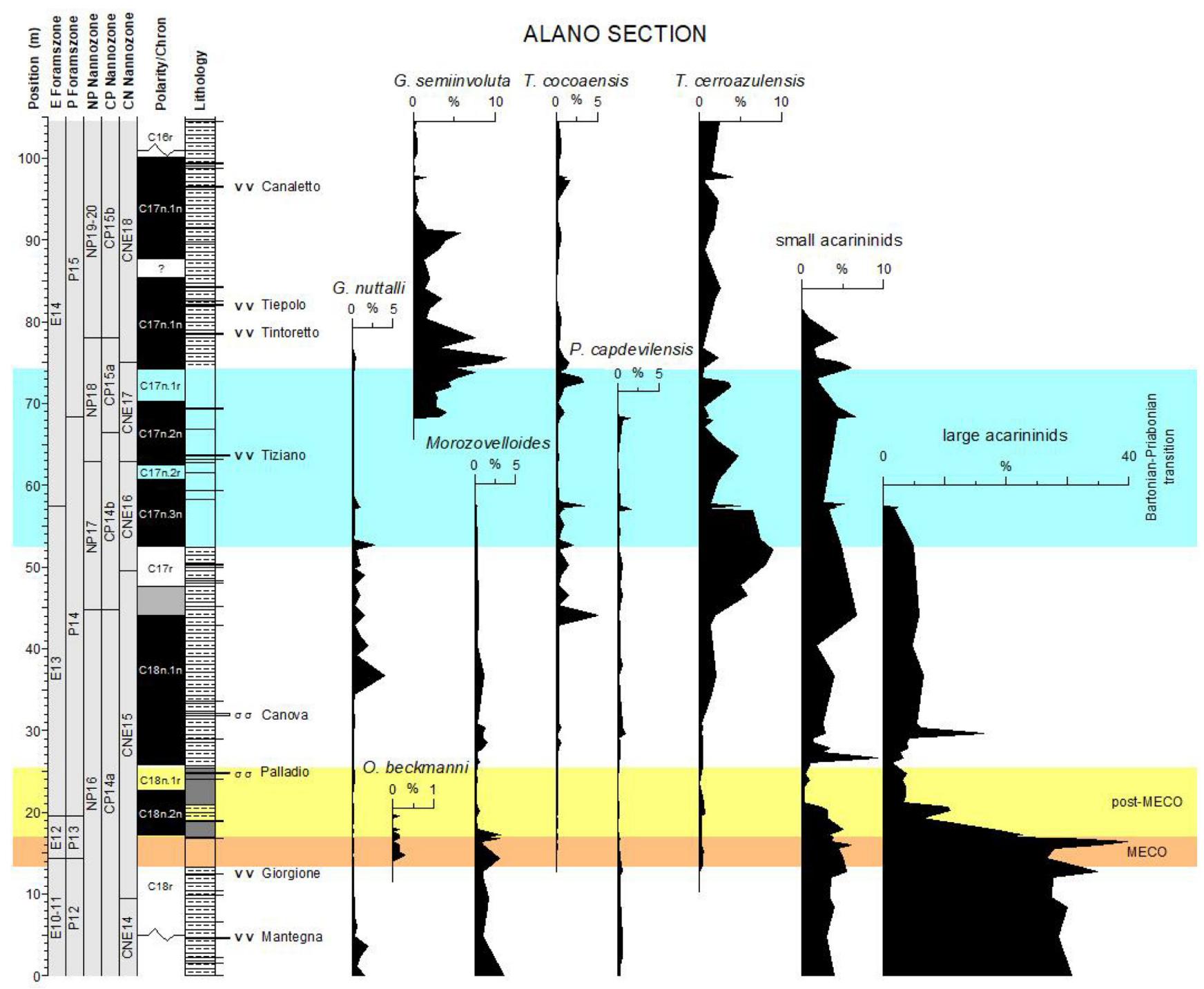

Figure 5. (modified after Agnini et al. 2011). Planktonic foraminiferal data and resulting biostratigraphic classification of the Alano section according to the zonal schemes of Berggren et al. (1995), Berggren and Pearson (2005) or Wade et al., (2011). Calcareous nannofossil biozonations are after Martini (NP; 1971), Okada and Bukry (CP; 1980) and Agnini et al., (CN; 2014). The relative abundance of each taxon is reported in terms of percentage with respect to the entire assemblage. The shaded orange band indicates the MECO, the shaded yellow band marks the post-MECO interval and the light blue shaded band identifies the Bartonian-Priabonian transition, the critical interval where the Priabonian GSSP should be defined.

with a high reproducibility and good correlation potentials through the candidate interval for the GSSP. They are closely spaced, with the Top of large acarininids and Morozovelloides preceding the Base of common and continuous C. erbae and the Top of C. grandis by $\sim 230 \mathrm{kyr}$, if a floating chronology based on cycle counting is adopted (Fig. 3; Galeotti et al., 2019).

The good magnetostratigraphy available at Alano (Agnini et al., 2011) as well as the astrochronology based on cycle counting of $\delta^{13} \mathrm{C}$ and wt.\% $\mathrm{CaCO}_{3}$ records and $\mathrm{U}-\mathrm{Pb}$ radio-isotopic dating (Galeotti et al., 2019), represent important additional datasets that improve the correlation potential of the Priabonian GSSP. In conclusion, recent research has confirmed that the Alano section is an appropriate section for defining the Priabonian GSSP, i.e., for the Bartonian/Priabonian boundary.

\section{Summary on Background Studies on the Alano Section}

The entire Alano section has been described and studied in detail by Agnini et al. (2011) and Fornaciari et al. (2010). Cyclostratigraphic study and radioisotopic analyses have recently been performed in the Alano section (Galeotti et al., 2019), and a correlation between the bathyal Alano and Varignano sections (Belluno and Lombardian basins, respectively) has been attempted (Luciani et al., 2020). In addition, the basal portion of this sedimentary sequence has been the object of recent studies (Spofforth et al., 2010; Luciani et al., 2010; Toffanin et al., 2011; BoscoloGalazzo et al., 2013, 2016) revealing the occurrence of a detailed record of the Middle Eocene Climatic Optimum (MECO; Bohaty and Zachos, 2003; Bohaty et al., 2009). 


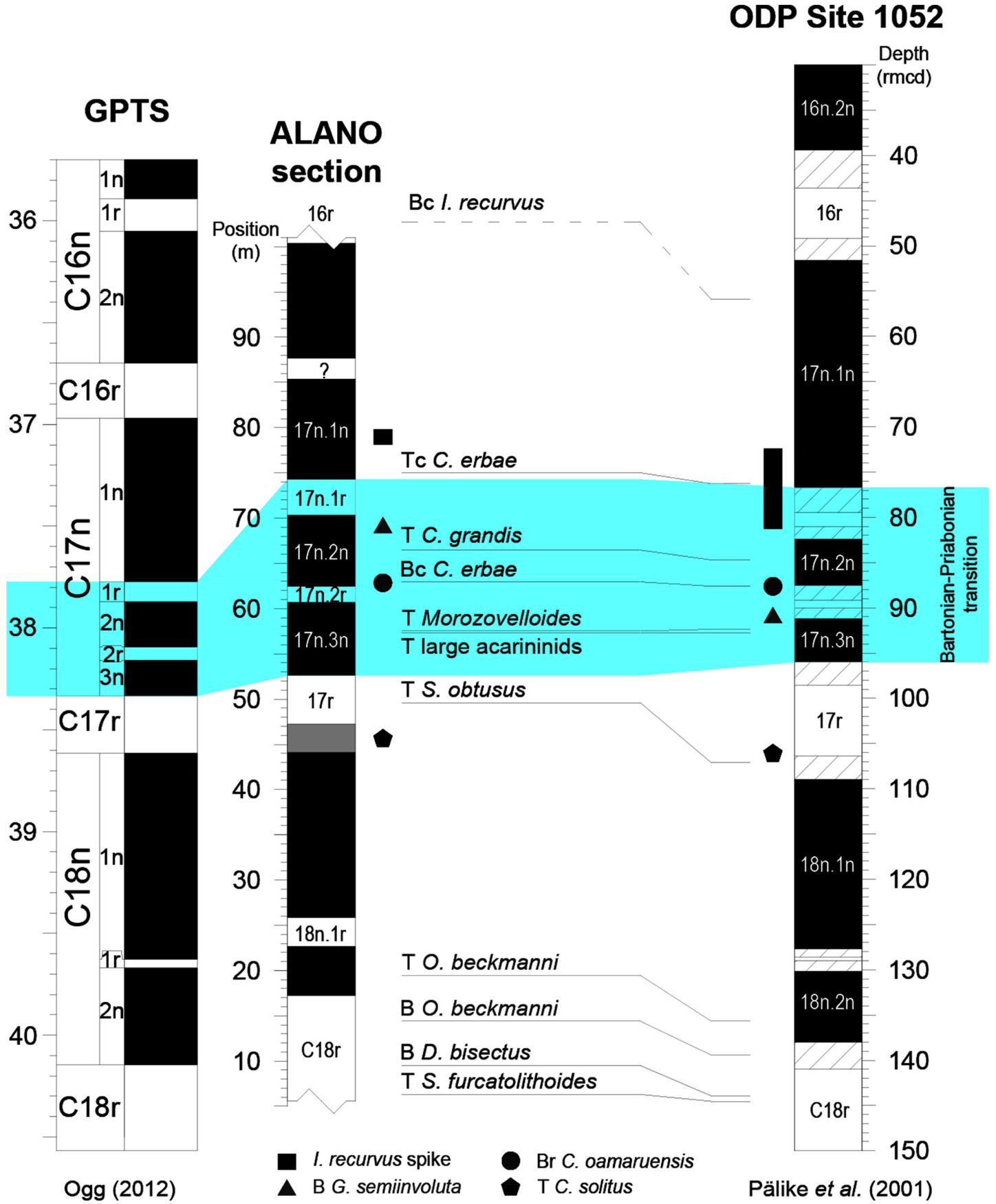

Figure 6. (modified after Agnini et al. 2011). Calcareous plankton correlation between the Alano section and ODP Site 1052 (western North Atlantic; Pälike et al., 2001) and resulting interpretation of the magnetostratigraphy of the Alano section. The geomagnetic polarity time scale of Ogg (2012; GTS12) is plotted on the left side. The light blue shaded band identifies the Bartonian-Priabonian transition, the critical interval where the Priabonian GSSP should be defined.

\section{Geological Setting}

The Alano section at Alano di Piave is located in the Italian Southern Alps (NE Italy; Fig. 1), a major structural element of the Alpine chain, interpreted as a south verging fold-and-thrust belt (Doglioni and Bosellini, 1987) resulting from the polyphase deformation of the southern margin of the Mesozoic Tethyan ocean (Bernoulli, 1972). In particular, the Alano section crops out in the Venetian Southern Alps (Fig. 1), and its constituent sediments deposited in the Belluno Basin, a paleogeographic domain resulting from the drowning of Triassic-Lower Jurassic shallow-water carbonate platforms (Winterer and Bosellini, 1981). Deep-water facies persisted in the south-western sector of the Belluno Basin, surrounded by shallower areas to the west (the Lessini Shelf; Bosellini, 1989) and east (the Friuli Platform; Fig. 1), until the late Eocene (Cita, 1975; Trevisani, 1997). The Alano section is located $\sim 8 \mathrm{~km} \mathrm{NNE}$ from the well-known Priabonian beds of the Possagno section (Bolli, 1975). More details on the geological context and evolution of the study area are given in Agnini et al. (2011). 


\section{The Stratigraphic Succession}

The Alano section mainly consists of greyish hemipelagic marls intercalated with a number of millimeter to centimeter thick sandy- silty layers, which are particularly useful as marker beds along the section (Figs. 7, 8). The general bedding strike is $130-140^{\circ} \mathrm{N}$ and the dip is $\sim 20-25^{\circ} \mathrm{S}$. Apart from being tilted, the section is unaffected by significant structural deformation. The sandy layers can be easily traced
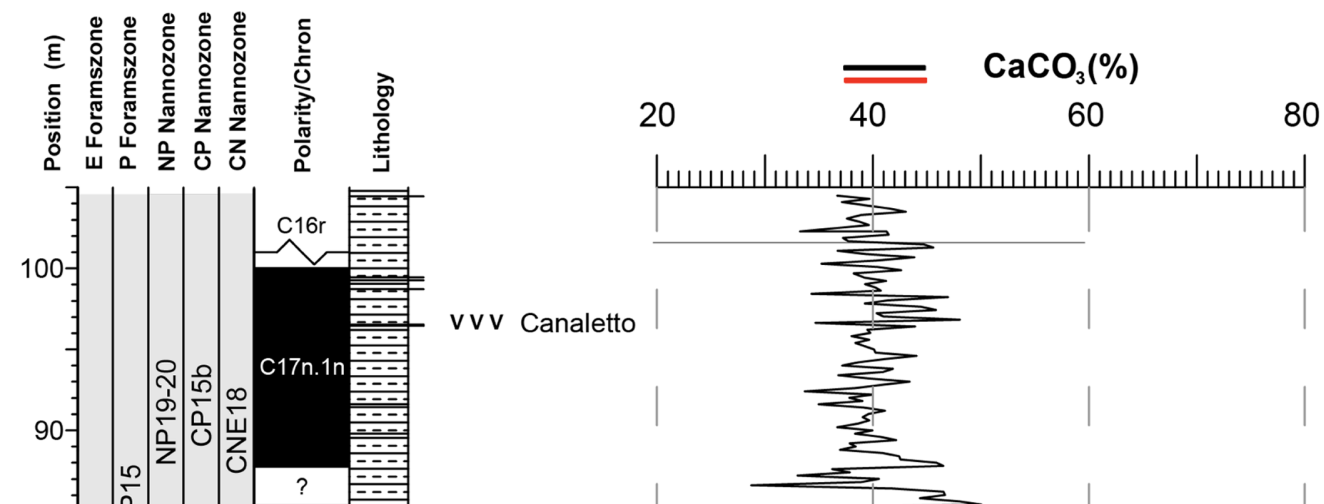

$\mathrm{O}_{3}(\%)$
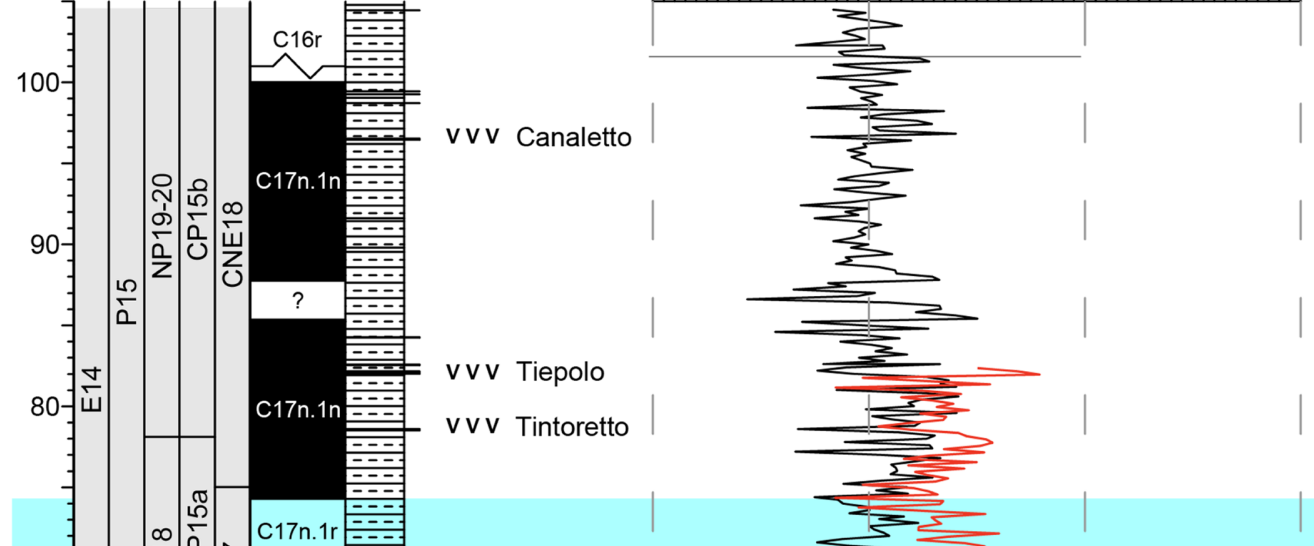


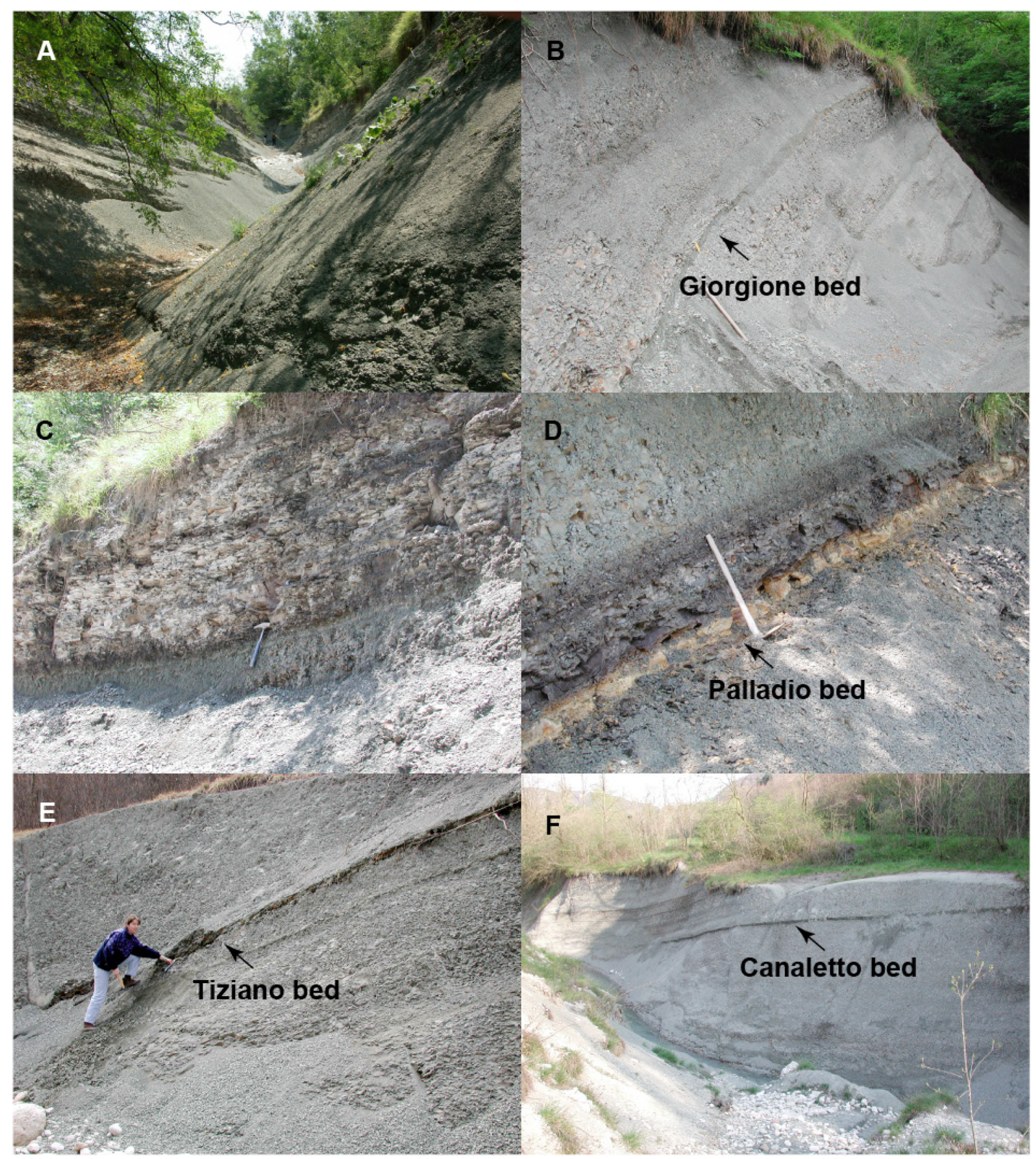

Figure 8. Alano section (modified after Agnini et al., 2011). (A) View of the lower part of the Alano section (lithozone A). (B) Detail of lithozone $A$ with indication of the crystal tuff layer Giorgione. (C) Basal portion of the sapropelic interval, the lithological expression in the study area of the post-MECO (lithozone B). (D) The upper part of the sapropelic interval with indication of the prominent bioclastic layer Palladio (lithozones B and C). (E) Close-up view of the critical interval showing the prominent crystal tuff layer Tiziano (basal lithozone D). (F) Upper part of the sampled section with indication of the crystal tuff layer Canaletto (lithozone D).

laterally and no faults (even with small displacement) are visible in the section. The sediments cropping out in the Alano section have not been deeply buried as testified by the good preservation of microfossils and the scarce maturity of the organic matter (Spofforth et al., 2010). The Alano section is continuously exposed along the banks of the Calcino Creek for at least 500 meters (Figs. 2, 8). Above the investigated section, there are an additional fifteen meters of continuously outcropping marls followed downstream by spotted outcrops. In the lower part of the section, from $\sim 17 \mathrm{~m}$ level to $\sim 25 \mathrm{~m}$ level, the grey marls facies is interrupted by a distinctive $\sim 8 \mathrm{~m}$-thick package of laminated dark to black organic-rich clayey marls (ORG1 and ORG2), which is interpreted as the 'post-MECO interval' (Luciani et al., 2010). Among the sandy-silty layers, eight are more than $6 \mathrm{~cm}$ thick, and six of these are crystal tuff layers that have been named, from the bottom to the top, after famous Venetian painters: Mantegna, Giorgione, Tiziano, Tiepolo, Tintoretto and Canaletto (Figs. 7, 8). The other two layers are 
biocalcarenite-rudite beds that have been named Palladio and Canova after famous Venetian artists (Figs. 7, 8). Field observations and a $\mathrm{CaCO}_{3}$ record permit the subdivision of the section into four lithozones: A, B, C and D (Agnini et al., 2011; Fig. 7). The Tiziano crystal tuff layer, here proposed as the GSSP of the Priabonian, occurs in the lower portion of lithozone D (which extends from $59.95 \mathrm{~m}$ to the top of the section; Fig. 7). Because none of the existing local lithostratigraphic units (Cita, 1975) can be properly applied to the succession cropping out at Alano, Agnini et al. (2011) provisionally introduced the informal term Marna scagliosa di Alano for the grey marls cropping out in the Alano section (Fig. 2).

\section{Depositional Environment and Correlation Between Deep- and Shallow-water Settings}

The grey marls of the Alano section were deposited in a low energy,

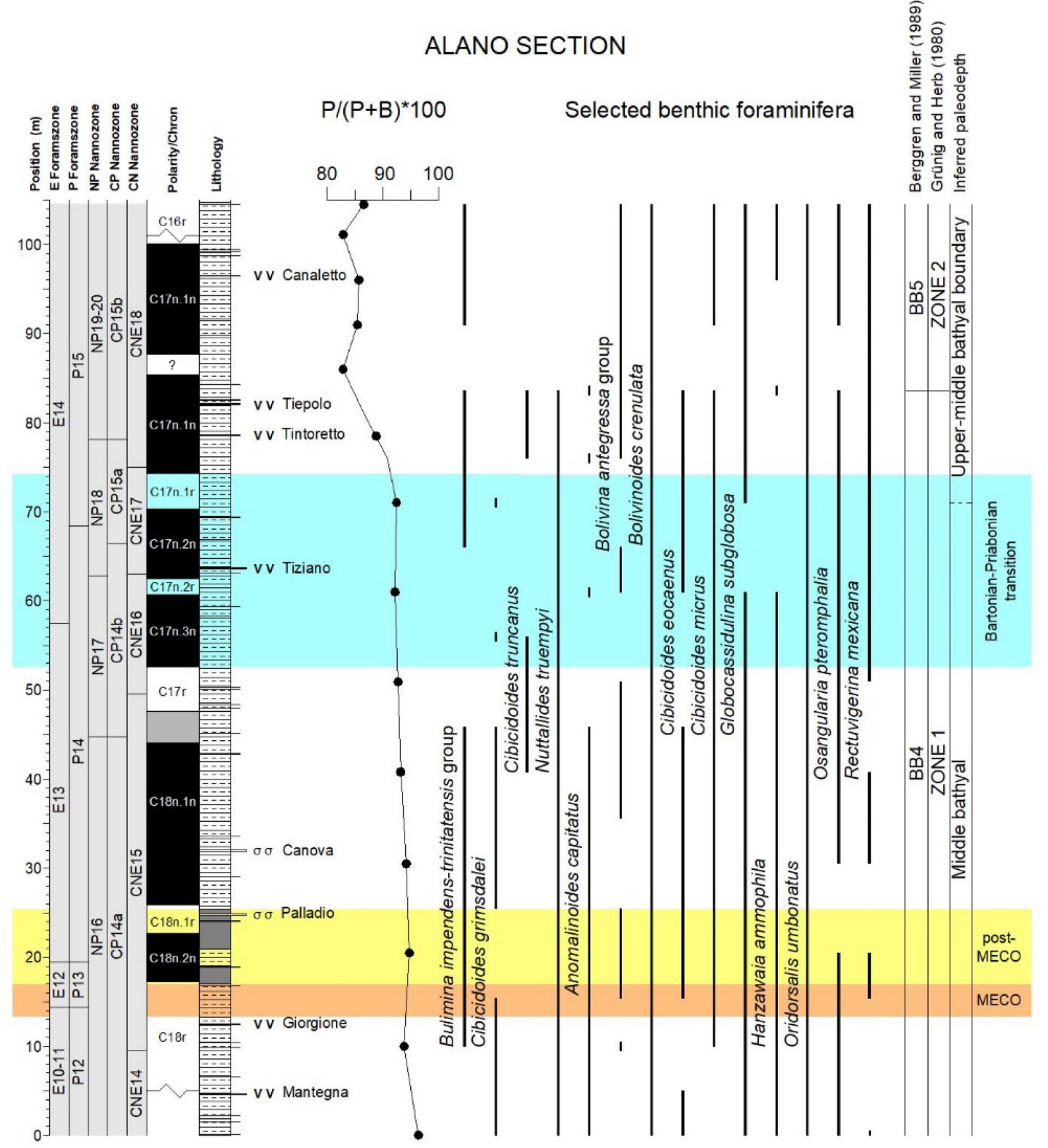

Figure 9. (modified after Agnini et al., 2011). The P/(P+B) (\%) (= planktonic to planktonic and benthic ratio) and stratigraphic distribution of selected small benthic foraminifera plotted against lithology and calcareous plankton biostratigraphy (P - Berggren et al. 1995; $E$ - Berggren and Pearson (2005) or Wade et al. (2011); NP-Martini, 1971; CP - Okada and Bukry, 1980; CN-Agnini et al., 2014). Benthic foraminifera biozonation (Berggren and Miller, 1989), bathymetric zonation (Grünig and Herb, 1980) and inferred paleodepth of the Alano section are reported on the right side. The shaded orange band indicates the MECO, the shaded yellow band marks the post-MECO interval and the light blue shaded band identifies the Bartonian-Priabonian transition, the critical interval where the Priabonian GSSP should be defined. 
open marine slope-basin setting. Paleobathymetric estimates point to a middle bathyal depositional depth (600-1000 m) for the lower two thirds of the section, and to upper-middle bathyal depths $(\sim 600 \mathrm{~m})$ for the remaining third of the studied section (Fig. 9; Agnini et al., 2011). This interpretation is supported by the Planktonic/Benthic foraminiferal ratio and by the changes observed in the benthic foraminiferal paleobathymetric indexes (Fig. 9; Agnini et al., 2011). Benthic fora- miniferal assemblages (Boscolo-Galazzo et al., 2013) indicate well oxygenated bottom waters throughout the entire section, except for the $8 \mathrm{~m}$-thick package of organic-rich sediments (17-25 $\mathrm{m}$ level), the 'post-MECO' interval, where hypoxic conditions prevailed, as also indicated by geochemical proxies (Spofforth et al., 2010). The abundant occurrence of bolivinids is typical of bathyal hemipelagic sediments in this area of the Tethys and has been related to the proximity

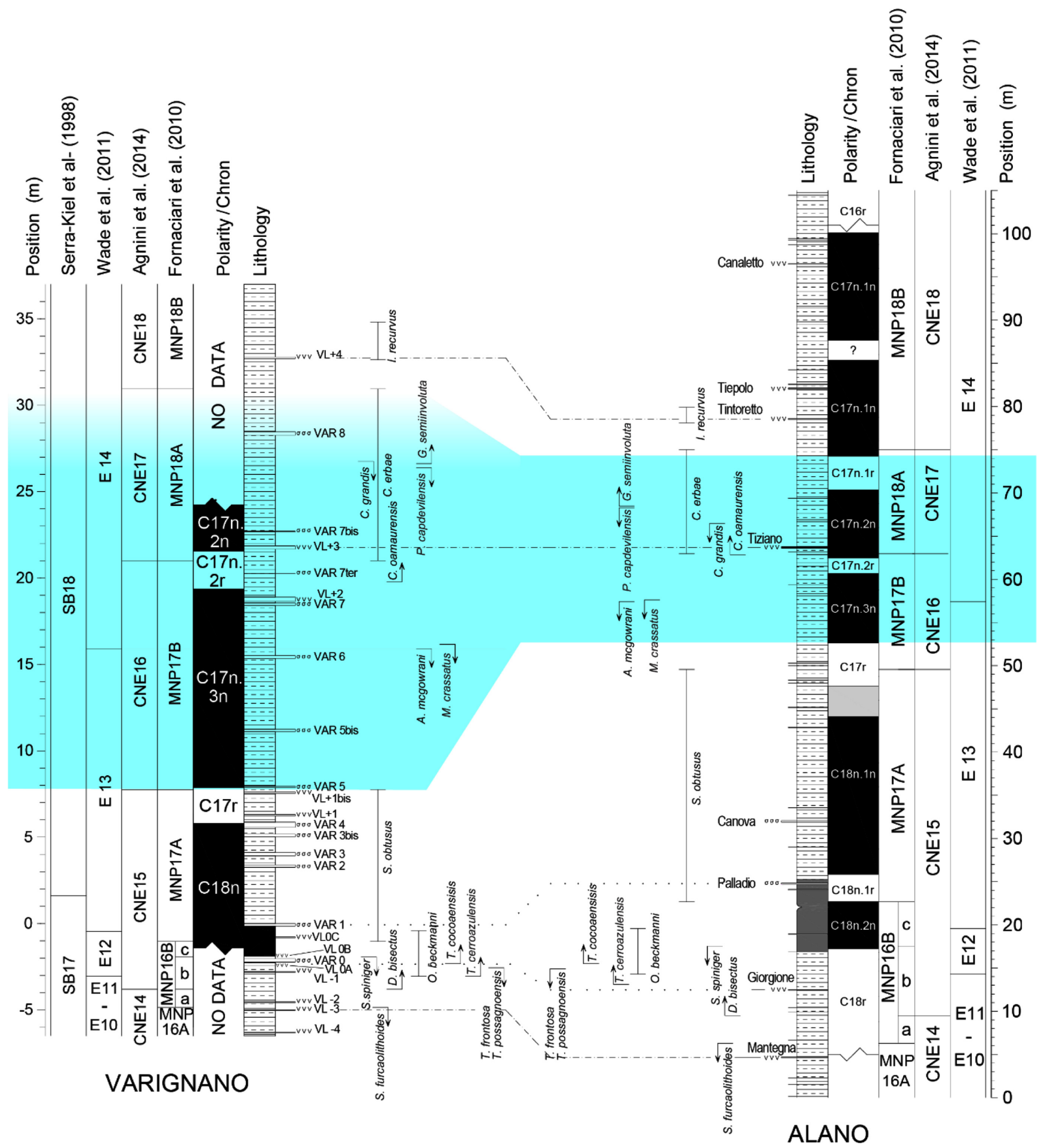

Figure 10. (modified after Luciani et al., 2020). Correlation of main and secondary calcareous plankton events and layers with volcanoclastic material (dashed line) recorded in the Varignano (Trento) and Alano (Belluno) sections. The light blue shaded band identifies the BartonianPriabonian transition, the critical interval where the Priabonian GSSP should be defined. Dashed lines refer to tentative correlations. 
of land (Boscolo-Galazzo et al., 2013). As expected in deep-water sediments like those of the Alano section, macrofossils are sporadic.

At Alano, larger foraminifera occur only as re-sedimented grains in distinct beds well below the critical interval, hampering a direct correlation between calcareous plankton and larger foraminiferal zonations. However important supporting information is provided by the Varignano section (Trento Province, Italy), located $\sim 80 \mathrm{~km}$ to the west of Alano, which preserves several coarse bioclastic levels rich in larger foraminifera intercalated within the bathyal marls of the Bartonian-Priabonian transition (Papazzoni et al., 2014; Luciani et al., 2020). The Varignano section contains a crystal tuff layer that is equivalent to the Tiziano bed as demonstrated by bio-magnetostratigraphical and petrographical-mineralogical data (Fig. 10; Luciani et al., 2020).

Primary and secondary calcareous plankton bioevents across the critical interval are recorded in the same order and stratigraphic position as observed at Alano (Fig. 10). In the succession, the direct correlation between calcareous plankton and larger foraminiferal zones clearly demonstrates that the Base of Zone SB19 is positioned significantly higher that the Bartonian-Priabonian transition as found in other recent studies (Papazzoni et al., 2014; Cotton et al., 2017; Rodelli et al., 2018; Luciani et al., 2020). Instead, this interval as identified by the calcareous plankton events discussed above correlates with the middle part of Zone SB18, the base of which is marked by the Base of the distinctive genus Pellatispira (Papazzoni et al., 2014).

\section{Calcareous Nannofossil Biostratigraphy}

Calcareous nannofossil assemblages are rich, well preserved, and diverse throughout the section (Plate I; Fornaciari et al., 2010; Agnini et al., 2011; Toffanin et al., 2011). The assemblages are dominated by placoliths, among which Cribrocentrum, Cyclicargolithus and Dictyococcites are prominent (together up to $\sim 70$ of the total assemblage). Chiasmolithus is very rare at Alano as is normally reported for low to middle latitude areas (Perch Nielsen, 1985; Wei and Wise, 1989); this is problematic because some biohorizons used in Martini's (1971) and Okada and Bukry's (1980) zonations, are based on Chiasmolithus species (Top of C. solitus - Base of Zone NP17 and Subzone CP14b; Base of C. oamaruensis - Base of Zone NP18, Top of C. grandis - Base of Subzone CP15a). The subdivision of NP and CP zonations is both difficult to apply and generally results in poor global correlations. Recently, a new calcareous nannofossil Paleogene biozonation has been published for low to middle latitudes (Agnini et al., 2014). This biostratigraphic scheme avoids the use of biohorizons based on Chiasmolithus species in favor of more reliable events (e.g., Base of common and continuous (Bc) of Dictyococcites bisectus, Top of Sphenolithus obtusus, Base of common and continuous and Top of common and continuous (Tc) C. erbae). With reference to this biozonation, the Alano section spans from Zone CNE14 to Zone CNE18 (Fig. 4). If the classical calcareous nannofossil zonation of Martini (1971) is followed, the Alano section covers the interval from Zone NP16 to undifferentiated Zone NP19-20 (Fig. 7). Finally, if the zonal scheme of Okada and Bukry (1980) is applied, the section extends from Subzone CP14a to Subzone CP15b (Fig.4). Agnini et al. (2011) demonstrated that the Tiziano Bed (63.57 m level) is 0.72 meters above the Base of uneven and rare $(\mathrm{Br})$ C. oamaruensis (62.85 m level), which marks the NP17/ NP18 boundary, and 2.90 meters below the Top of $C$. grandis, which defines the Subzone CP14b/ Subzone CP15a boundary. Because of the general scarcity of these taxa, these biohorizons must be used with caution for accurate correlations. The Base of common and continuous C. erbae (62.96 m level), as defined in Agnini et al. (2014), is recorded 0.61 meters below the base of the Tiziano bed, and represents the most reliable calcareous nannofossil biohorizon for approximating the base of the Priabonian (Fornaciari et al., 2010; Agnini et al., 2011). A more global perspective of calcareous nannofossil biohorizons across the Bartonian-Priabonian transition as well as their degree of reliability and correlatability are presented in Figure 6, where the Alano section and the reference ODP Site 1052 are compared (Agnini et al., 2011).

\section{Planktonic Foraminiferal Biostratigraphy}

Planktonic foraminifera are continuously present, abundant and diverse throughout the Alano section, except for some levels of the organic rich package (from $17 \mathrm{~m}$ level to $25 \mathrm{~m}$ level), the 'post-MECO' interval (Figs. 5, 8; see Plate II for iconographic material). The preservation varies from moderate to good and foraminiferal assemblages are generally recognizable although commonly recrystallized, cemented and infilled. The assemblage composition is distinctive of subtropical-temperate latitudes and changes in the relative abundance of taxa are observed throughout the section. Subbotinids and globigerinathekids are among the more frequent and common groups.

Large acarininids are abundant in the lower part of the section and include Acarinina with well-developed muricae and test size $>125 \mu \mathrm{m}$ (A. bullbrooki, A. mcgowrani, A. praetopilensis, A. primitiva, A. rohri, A. topilensis). This group decreases at the ORG1 and ORG2 intervals (Spofforth et al., 2010) corresponding to the 'post-MECO' as defined by Luciani et al. (2010). The hantkeninids display a sporadic distribution and, where present, constitute a minor component of the assemblage. With reference to the standard zonation of Berggren et al. (1995), the Alano section extends from Zone P12 to Zone P15. In terms of the tropical to subtropical zonation of Berggren and Pearson (2005) and the subsequent revision by Wade et al. (2011), the section extends from undifferentiated Zone E10-11 to Zone E14. At Alano, the identification of the Top of Orbulinoides beckmanni (19.5 m level; Fig. 5), marking the E12/E13 and P13/P14 boundaries, is difficult to recognize because of the scarcity of this taxon and the moderate preservation of the foraminiferal assemblages in the 'post-MECO' interval. The E10 and E11 zones (Berggren and Pearson, 2005; Wade et al., 2011; Payros et al., 2015) have been merged because at Alano the highest consistent occurrence of Guembelitrioides nuttalli, which marks the Base of Zone E11, is recorded at $57.52 \mathrm{~m}$ level, well above the Top of $O$. beckmanni. The extinction level of large acarininids occurs at $57.32 \mathrm{~m}$ level and is immediately followed (57.52 m level; Fig. 5) by the disappearance of Morozovelloides (i.e., Morozovelloides crassatus and Morozovelloides coronatus). These biohorizons underlie the Tiziano bed by 6.25 and 6.05 meters respectively, which is equivalent to $170-173 \mathrm{kyr}$ in our floating chronology (Fig. 3). To test the reliability and reproducibility of the Top of large acarininids and Morozovelloides, we compared the Alano section with the reference ODP Site 1052 (Fig. 6; Wade, 2004; Agnini et al., 2011). This pair of closely spaced bioevents is very solid and provides a good correlation tool to approximate the base of the Priabonian (Wade et al., 2012). 


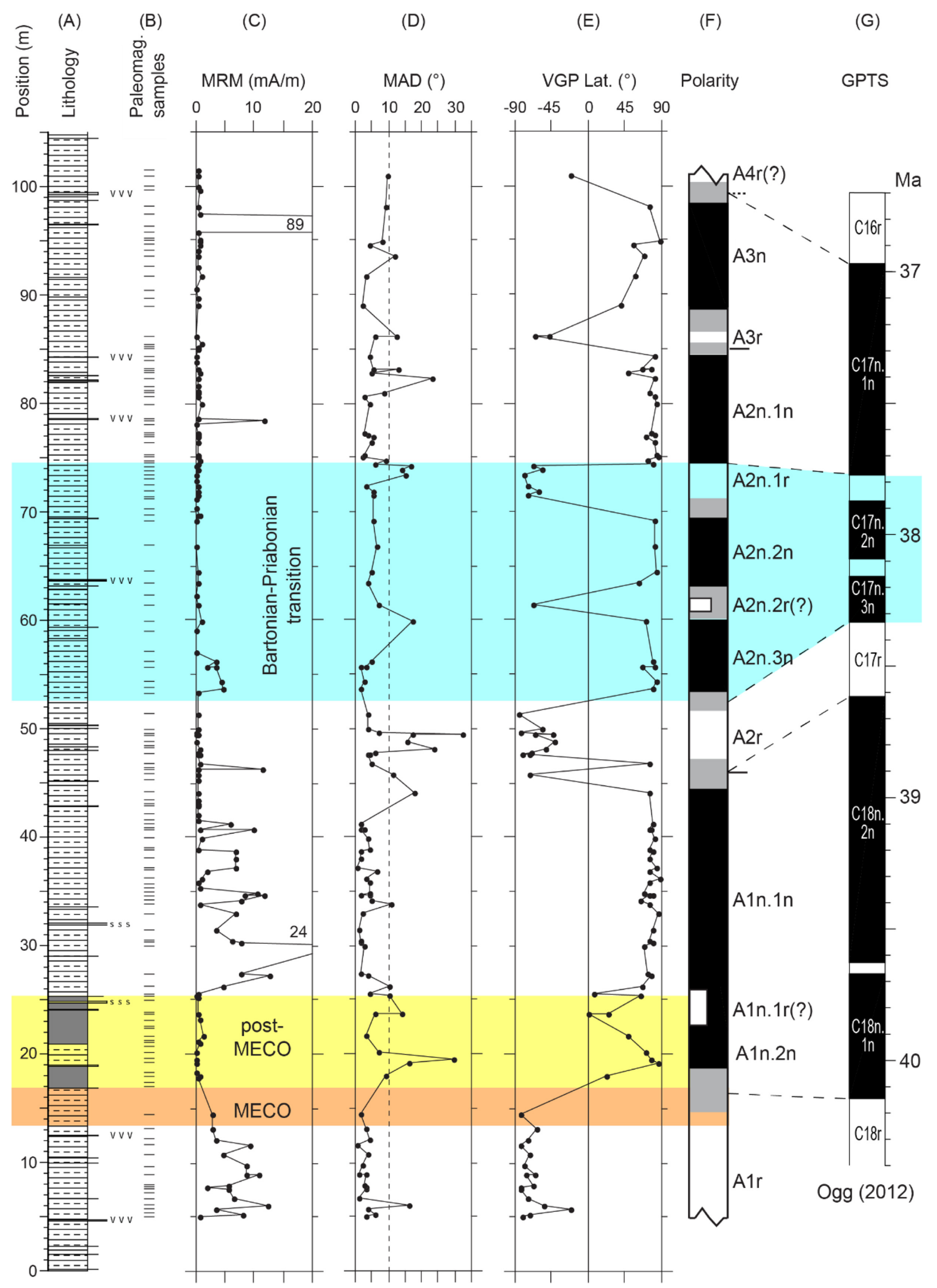

Figure 11. (modified after Agnini et al., 2011). Stratigraphic synthesis of the Alano section with (A) lithology, (B) stratigraphic position of samples for paleomagnetic analysis, (C) natural remanent magnetization (NRM) intensity, (D) mean angular deviation (MAD) of the characteristic magnetic component, and (E) virtual geomagnetic pole (VGP) latitude used for polarity interpretation (F); black is normal polarity; white reverse polarity; (G) GPTS (Ogg, 2012; GST12). The shaded orange band indicates the MECO, the shaded yellow band marks the postMECO interval and the light blue shaded band identifies the Bartonian-Priabonian transition, the critical interval where the Priabonian GSSP should be defined. 


\section{Magnetostratigraphy}

The Alano section has a good magnetostratigraphic record, which permits a straightforward correlation to the geomagnetic polarity time scale of Ogg (2012; GTS12 Fig. 11). An overall sequence of 13 polarity magnetozones has been established starting from the base up to the top of the section (Agnini et al., 2011). The basal part of the section correlates with the upper part of Chron C18r, while the single sample with reverse polarity at the top of the section correlates with the Base of Chron C16r (Fig. 11). Though the base of the Priabonian has often been approximated by the Base of Subchron C17n.1n (see discussion in Vandenberghe et al., 2012), the polarity reversal with the higher correlation potential in the proximity of the Tiziano bed is the Base of Chron C17n (or Subchron C17n.3n) at $52.62 \mathrm{~m}$ level. It is worth not- ing that the polarity reversal closest to the Tiziano bed is the Base of Subchron C17n.2n (62.48 m level). The latter is defined by a single reversed datapoint. However, assuming the median points of related uncertainty intervals as base and top of this Subchron, its cyclochronological duration is consistent with the adopted timescales (Galeotti et al., 2019).

\section{Stable isotopes (bulk $\delta^{13} \mathrm{C}$ and $\delta^{18} \mathrm{O}$ ) and the Middle Eocene Climatic Optimum}

Carbon and oxygen stable isotopes $\left(\delta^{13} \mathrm{C}\right.$ and $\left.\delta^{18} \mathrm{O}\right)$ analyses were performed on bulk rock from the entire section with an average sample spacing of $\sim 20 \mathrm{~cm}$ (Fig. 12; Spofforth et al., 2010). The $\delta^{13} \mathrm{C}$ and $\delta^{18} \mathrm{O}$ profiles show a gradual decrease of $\sim 0.5 \%$ up section. No sig-

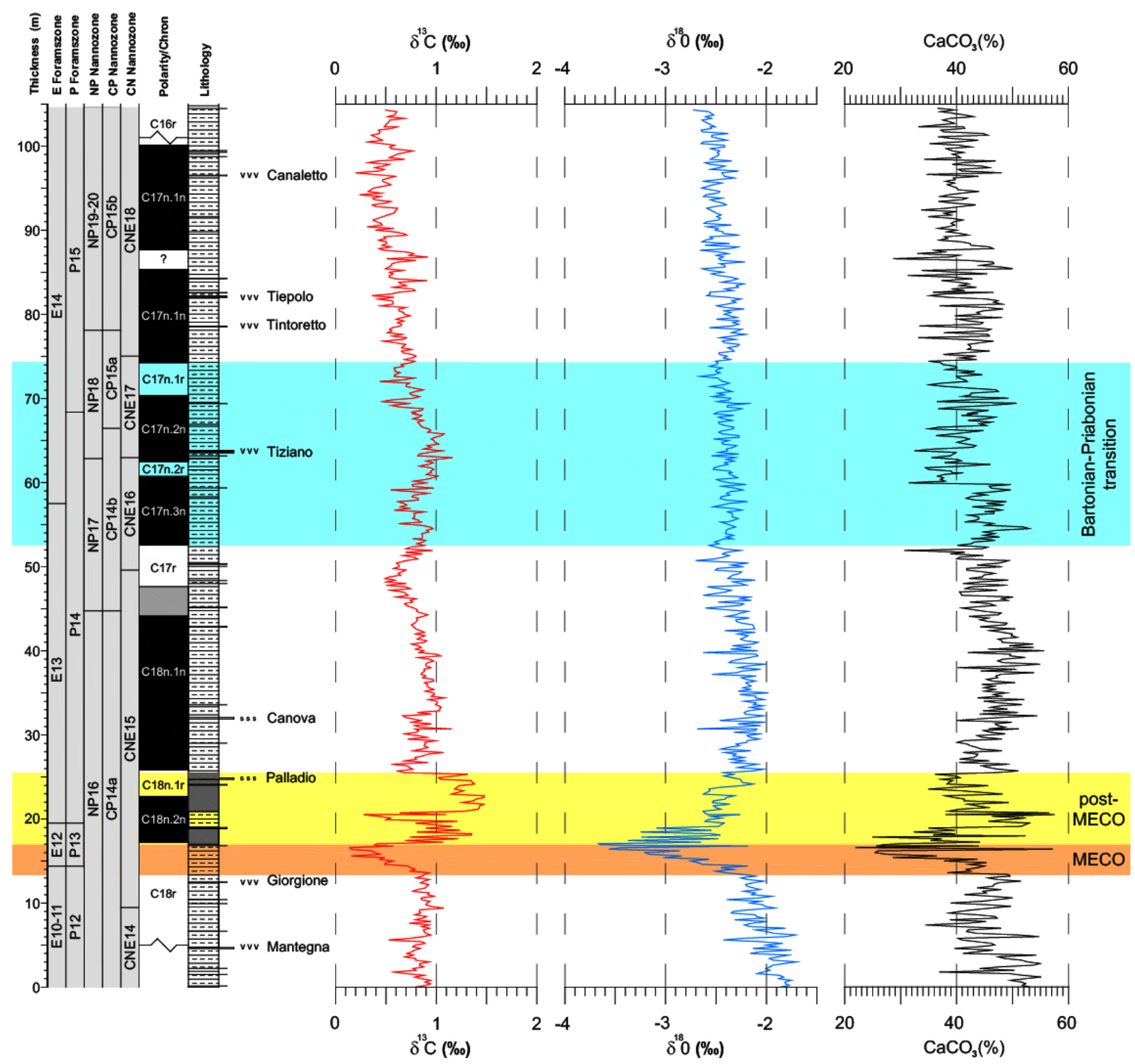

Figure 12. (modified after Spofforth et al., 2010). Bulk carbonate stable isotopes $\delta^{13} \mathrm{C}, \delta^{18} \mathrm{O}$, and percentage CaCO $\mathrm{O}_{3}$ over the entire Alano section. The shaded orange band indicates the MECO, the shaded yellow band marks the post-MECO interval and the light blue shaded band identifies the Bartonian-Priabonian transition, the critical interval where the Priabonian GSSP should be defined. 
Table 1. Absolute and relative (to the Tiziano bed) position (m) and chronology of events at the Bartonian - Priabonian transition.

\begin{tabular}{|c|c|c|c|c|c|c|c|c|c|c|c|c|}
\hline \multirow[b]{2}{*}{ Event/Marker } & \multirow[b]{2}{*}{$\begin{array}{l}\text { Position } 1 \\
\text { (m) }\end{array}$} & \multirow[b]{2}{*}{$\begin{array}{l}\text { Position } \\
\text { relative to } \\
\text { Tiziano } \\
\text { bed }(m)\end{array}$} & \multirow[b]{2}{*}{$\begin{array}{l}\text { Notation } \\
\text { relative to } \\
\text { Chron Top }\end{array}$} & \multicolumn{3}{|c|}{ Galeotti et al. (2019) } & \multicolumn{2}{|c|}{ CK95 } & \multicolumn{2}{|r|}{ PÄ06 } & \multicolumn{2}{|r|}{ W14 } \\
\hline & & & & $\begin{array}{c}\text { Age } \\
\text { (U-Pb } \\
\text { dating) } \\
\text { (Ma) }\end{array}$ & $\begin{array}{l}\text { Age (astro- } \\
\text { chronol- } \\
\text { ogy) (Ma) }\end{array}$ & $\begin{array}{c}\text { Time rela- } \\
\text { tive to the } \\
\text { Tiziano } \\
\text { bed (kyr)* }\end{array}$ & $\begin{array}{l}\text { Age } \\
\text { (Ma) }\end{array}$ & $\begin{array}{l}\text { Time rela- } \\
\text { tive to the } \\
\text { Tizianobed } \\
(\mathrm{kyr})^{* *}\end{array}$ & $\begin{array}{l}\text { Age } \\
\text { (Ma) }\end{array}$ & $\begin{array}{l}\text { Time rela- } \\
\text { tive to the } \\
\text { Tiziano bed } \\
(\mathrm{kyr})^{* *}\end{array}$ & $\begin{array}{l}\text { Age } \\
\text { (Ma) }\end{array}$ & $\begin{array}{l}\text { Time rela- } \\
\text { tive to the } \\
\text { Tiziano bed } \\
(\mathrm{kyr})^{* *}\end{array}$ \\
\hline Subchron C17n.1n base & 74.28 & 10.71 & C17n.1n 1.00 & 37.402 & 37.380 & 340 & 37.473 & 341 & 37.520 & 352 & 37.385 & 361 \\
\hline B G. semiinvoluta & 68.37 & 4.8 & C17n.2n 0.25 & 37.600 & 37.578 & 142 & 37.665 & 149 & 37.719 & 153 & 37.593 & 153 \\
\hline T C. grandis & 66.47 & 2.9 & C17n.2n 0.49 & 37.664 & 37.657 & 63 & 37.724 & 90 & 37.780 & 92 & 37.654 & 92 \\
\hline TIZIANO BED & 63.57 & 0 & C17n.2n 0.86 & 37.762 & 37.710 & 0 & 37.814 & 0 & 37.872 & 0 & 37.746 & 0 \\
\hline Bc C. erbae & 62.96 & -0.61 & C17n.2n 0.94 & 37.782 & 37.740 & -20 & 37.833 & -19 & 37.892 & -20 & 37.766 & -20 \\
\hline $\mathrm{Br}$ C. oamaruensis & 62.85 & -0.72 & C17n.2n 0.95 & 37.786 & 37.742 & -22 & 37.837 & -23 & 37.895 & -23 & 37.769 & -23 \\
\hline Subchron C17n.2n base & e 62.48 & -0.48 & C17n.2n 1.00 & 37.798 & 37.772 & -30 & 37.848 & -34 & 37.907 & -35 & 37.781 & -35 \\
\hline T M. crassatus & 57.52 & -6.05 & C17n.3n 0.39 & & 37.890 & -170 & 37.996 & -182 & 38.036 & -164 & 37.946 & -200 \\
\hline $\mathrm{T}$ large acarininids & 57.32 & -6.25 & C17n.3n 0.42 & & 37.893 & -173 & 38.001 & -187 & 38.040 & -168 & 37.951 & -205 \\
\hline Subchron C17n.3n base & e 52.62 & -10.95 & C $17 n .3 n 1.00$ & & 38.090 & -290 & 38.113 & -299 & 38.158 & -286 & 38.081 & -335 \\
\hline
\end{tabular}

*Time (kyr) relative to the Tiziano bed

**Time (kyr) relative to the Tiziano bed assuming constant linear sedimentation rates within Chrons

CK95 - Cande \& Kent (1995); PÄ06 - Pälike et al. (2006); W14 - Westerhold et al. (2014)

nificant variations occur at the Bartonian-Priabonian transition except for a slight gradual increase in $\delta^{13} \mathrm{C}$ values starting in the middle part of Subchron C17n.3n (+ $0.6 \%$ ) and culminating in the lower part of Subchron C17n.2n (+1.1\%o). By contrast, the lower part of the section, from $\sim 13 \mathrm{~m}$ level to $25 \mathrm{~m}$ level, is characterized by major and distinct shifts in both $\delta^{13} \mathrm{C}$ and $\delta^{18} \mathrm{O}$ records. A coupled negative excursion of $\delta^{13} \mathrm{C}$ and $\delta^{18} \mathrm{O}$ is documented from the $13 \mathrm{~m}$ level to $17 \mathrm{~m}$ level, which is interpreted as the Middle Eocene Climatic Optimum (MECO), being constrained within the upper part of Chron $\mathrm{C} 18 \mathrm{r}$ and the basal-most part of Subchron C18n.2n (Bohaty et al., 2009; Spofforth et al., 2010). Interestingly, after the climax of the event $(\sim 40.1$ Ma; Bohaty et al., 2009), from $\sim 17 \mathrm{~m}$ level to $\sim 25 \mathrm{~m}$ level, the $\delta^{18} \mathrm{O}$ record gradually recovers while the $\delta^{13} \mathrm{C}$ and $\mathrm{CaCO}_{3}$ profiles are more complex. Two positive excursions in $\delta^{13} \mathrm{C}$ of $\sim 1.25 \%$ associated with low carbonate content are interrupted by a rapid and transient return to climax conditions $(0.3 \%$ ) and an increase in carbonate content (Spofforth et al., 2010). This interval is named 'post-MECO' after Luciani et al. (2010) and is lithologically characterized by two sediment packages (ORG1 and ORG2 in Figs. 8, 12) with an elevated organic carbon content (up to $3 \%$ ). The response of benthic and planktonic foraminifera, and calcareous nannoplankton to the MECO and 'post-MECO' is the focus of a number of papers (Luciani et al., 2010; Toffanin et al., 2011; Boscolo-Galazzo et al., 2013; 2016).

\section{Orbital tuning and radioisotopic dating $\left({ }^{206} \mathrm{~Pb}_{-}{ }^{238} \mathrm{U}\right)$}

Galeotti et al. (2019) complemented the already existing data (calcareous plankton biostratigraphy, magnetostratigraphy, carbon and oxygen isotope, $\mathrm{CaCO}_{3}$ content) with a cyclochronology based on carbon isotope and wt.\% $\mathrm{CaCO}_{3}$ records and ${ }^{206} \mathrm{~Pb} /{ }^{238} \mathrm{U}$ dating of zircons from four volcanic tuffs throughout the interval spanning the Bartonian-Priabonian transition. Although small systematic discrepancies exist between orbital and radioisotopic age estimates of the Tiziano bed, the duration of intervals bracketing consecutive crystal tuff layers are in good overall agreement (Table 1). The age model obtained allows calculation of the duration of individual magnetochrons and calibrating biostratigraphic and non- biostratigraphic events at the BartonianPriabonian transition. This approach thus provides two very close independent numerical ages for the Tiziano bed, specifically $37.762 \pm$ $0.077 \mathrm{Ma}$ from the zircon ${ }^{206} \mathrm{~Pb} /{ }^{238} \mathrm{U}$ dating and $37.710 \pm 0.01 \mathrm{Ma}$ from astrochronology, that represent an additional but strongly suggested (by ICS) requirement when a GSSP is defined.

\section{Selecting the Boundary Level at Alano}

The historical review and discussion above indicates that the optimal interval for defining the base of the Priabonian and placing the "golden spike" lies between the Base of Subchron C17n.3n and the Base of Subchron C17n.1n according to correlatability and historical appropriateness criteria (Fig. 3).

The most widespread practice in proposing GSSPs has been and still is to locate the "golden spike" exactly in the lithologic level where a specific, arguably widely correlatable, biostratigraphic or magnetostratigraphic event occurs (Remane et al., 1996). Within this practice, there would be at least three viable options at Alano for defining the base of the Priabonian:

1. the Top of large acarininids and Morozovelloides (Base of Zone E14). As discussed above, these two closely spaced biohorizons represent very reliable events with a high correlation potential in the marine domain. These taxa are very distinctive and easy to recognize even in thin section, and are precisely calibrated (Wade et al., 2011; 2012).

2. the Base of C. oamaruensis (Base of Zone NP18). This biohorizon has been used for the past three decades to recognize the base of the Priabonian by some workers but, unfortunately, it is not a reliable biostratigraphic datum. However, if we still want to place the base of the Priabonian as close as possible to the Base of $C$. oamaruensis using calcareous nannofossils, the Base of common and continuous C. erbae (Base of Zone CNE17) and the Top of $C$. grandis (Base of Subzone $\mathrm{CP} 15 \mathrm{a}$ ) might be used to approximate this biohorizon; 
3. the Base of Chron C17n (Base of Subchron C17n.3n). This magnetic polarity event as part of a rapid series of magnetic reversals embedded in Chron 17 would allow correlations between expanded marine and continental sections well outside the proposed GSSP.

There is a significant practical problem with all these bio- and magnetostratigraphic events, namely that the Alano section is rapidly eroding which means (for posterity) that any GSSP marker will have to be accurately relocated as the section erodes. We are also mindful of the comment of Berggren et al. (1985) that: “...proper stratigraphic procedure requires that paleontologic criteria, although definitive for regional correlation (i.e. recognition) beyond the stratotype region, should not be part of the definition itself... (Hedberg, 1976)".

After much discussion of the relative merits of the various stratigraphic levels that might best serve as the boundary, we propose to define the Priabonian GSSP at a lithologic level (tuff layer Tiziano bed) that is easily recognizable in the field and around which the above set of events occurs. This rather unconventional choice of defining the base of a chronostratigraphic unit (Priabonian in this case) at a lithologic level that does not directly coincide with a biostratigraphic and/ or magnetostratigraphic event has the clear advantage of making the GSSP easily recognizable in the field as the Tiziano bed stands out clearly relative to the surrounding featureless and rapidly eroding marls.

The high number of closely spaced events that accompany the Tiziano Bed guarantees a high degree of correlatability of the Priabonian GSSP well outside the Alano section where it is formally defined.

Within this conceptual frame, we propose to the ICS that the base of the Priabonian is to be defined at the base of a prominent crystal tuff layer named the 'Tiziano bed', positioned at $63.57 \mathrm{~m}$ level in the Alano section. This is proposed as the primary marker horizon in the sense of Remane et al. (1996) and although we are aware that in and of itself it has limited and only local correlation potential, it is surrounded by a set of biostratigraphic and non-biostratigraphic events that permit easy correlation out of the GSSP section. Moreover it has the rare advantage of being amenable to direct and precise age-dating by radioisotopic methods (i.e., ${ }^{206} \mathrm{~Pb} /{ }^{238} \mathrm{U}$ zircon dates) which can then be compared with advantage to ages derived from interpolation between magnetic reversal datums on magnetochronologic timescales and astronomical dating using orbital cyclicity expressed in the sedimentary facies at Alano (Galeotti et al., 2019).

\section{The Proposed GSSP of the Priabonian}

The main motivation in proposing the base of the Tiziano bed in the Alano section as the base of the Priabonian Stage is that this level is surrounded by a key set of events that have good correlation potential and allow the recognition of the Priabonian Stage out of the section in which it is formally defined. The definition we propose here is historically appropriate and respectful of most of the commonly accepted paleontological events that have, historically, been used to approximate this boundary because:

1. It is in the same region as the historically important Priabona section that gives the stage its name, and in its auxiliary sections; the proposed GSSP lies stratigraphically below the base of the Priabona section and so incorporates it;

2. the double extinction of large acarininids and Morozovelloides, which have previously been considered to be within the Bartonian, would remain in the Bartonian;

3. The common and continuous presence of I. recurvus, which has widely been considered an intra-Priabonian calcareous nannofossil biohorizon, would remain in the Priabonian;

4. The Base of N. fabianii, which is considered an unquestionable Priabonian benthic larger foraminiferal biohorizon, would remain in the Priabonian. However, a limitation of the proposed definition concerns the stratigraphic range of several benthic larger foraminiferal taxa across the Bartonian-Priabonian transition and, specifically, there are some larger benthic foraminifera taxa traditionally considered to be Bartonian which could now lie in the Priabonian (e.g. Nummulites biedai and N. maximus).

Last but not least, as strongly suggested by the ICS revised guidelines, the Alano section meets a set of non-biostratigraphic requirements such as a solid magnetostratigraphic record, a firm astrochronological tuning based on cycle counting of $\delta^{13} \mathrm{C}$ and wt. $\% \mathrm{CaCO}_{3}$ records, complete carbon and oxygen isotope profiles, and a precise $\mathrm{U}-\mathrm{Pb}$ radioisotopic dating of the Tiziano Bed, the crystal tuff layer chosen to define the base of the Priabonian. It is also easily accessible and the GSSP will remain obvious despite being in a relatively rapidly eroding section.

\section{The proposed GSSP of the Priabonian}

Name of the boundary: Base of the Priabonian.

Rank of the Boundary: Stage/Age.

Position of the unit: Upper part of the Eocene Series, between the Bartonian (below) and the Rupelian (above) stages.

Type locality of the Global Stratotype Section and Point: Alano section at Alano di Piave, southern part of the Belluno Province, Veneto region, northeastern Italy, Europe.

Geographic location: The Alano section crops out for $\sim 500$ meters along the banks of the Calcino Creek, between the small villages of Colmirano and Campo, $\sim 1 \mathrm{~km}$ NE of Alano di Piave village. In correspondence to the section, the Calcino Creek has deeply eroded the Quaternary deposits exposing the marly substratum in banks of 2 up to 6 meters high, along which the succession is cropping out continuously. Latitude: $45^{\circ} 54^{\prime} 51.10^{\prime \prime N}$; Longitude: $11^{\circ} 55^{\prime} 4.87 " \mathrm{E}$ (WGS84; Fig. 1).

Map: The area is included on the "Carta Topografica d'Italia" at 1:25:000, Tavoletta Cavaso del Tomba, $\mathrm{F}^{\circ}$ 37, I S.E. A detailed geologic map of the Alano area is reported in Agnini et al. (2011; Fig. 2).

Accessibility: Alano di Piave village is easily reached by the regional roadway SR 348 and provincial roadway SP10. The easiest way to access the section is to pass the small Colmirano village and reach the soccer field indicated in Fig. 1. Departing from the parking area of the soccer field there is an easy walk of some $300-400 \mathrm{~m}$ in a plain grass field that leads you to the base of the section (Fig. 1).

Conservation: Since the end of 2013, the Alano section has been included in the Italian geosite inventory by the Institute for Environmental Protection and Research, ISPRA (Istituto Superiore per la Protezione e la Ricerca Ambientale) (http://sgil .isprambiente.it/geositiweb/ Default.aspx)

GSSP definition: The base of the Tiziano bed, a prominent crystal tuff layer positioned at $63.57 \mathrm{~m}$ level in the Alano di Piave section, is 
the GSSP of the base of the Priabonian Stage. An age of $37.762 \pm$ $0.077 \mathrm{Ma}(2 \sigma$ analytical and systematic uncertainty) Ma has been assigned to this level based on $\mathrm{U}-\mathrm{Pb}$ radioisotopic data complemented by an age of $37.710 \pm 0.01 \mathrm{Ma}$ based on counting astronomical cycles in the carbon isotope record (Galeotti et al., 2019). The Tiziano bed is $\sim 6$ meters above the Top of large acarininids $(57.32 \mathrm{~m} \mathrm{level})$ and Morozovelloides ( $57.52 \mathrm{~m}$ level) and close to the Base of common and continuous $C$. erbae ( $62.96 \mathrm{~m}$ level or $-0.61 \mathrm{~m}$ from the Tiziano bed) and Top of $C$. grandis ( $66.47 \mathrm{~m}$ level or $+0.49 \mathrm{~m}$ from the Tiziano bed) (Fornaciari et al., 2010; Agnini et al., 2011). The Base of Subchron C17n. $3 \mathrm{n}(52.62 \mathrm{~m}$ level) is positioned $\sim 11 \mathrm{~m}$ below the base of Tiziano bed, whereas the closest polarity inversion, i.e. the Base of Subchron C17n.2n (62.48 m level or $-1.09 \mathrm{~m}$ from the Tiziano bed), is just below the base the crystal tuff layer (Fig. 3; Table 1).

Identification in the field: The base of the 14-16 cm-thick green to grey tuff layer named the Tiziano bed. Identification in the field and resampling of the section are facilitated by the presence of multiple sandy-silty layers that represent useful marker beds along the section. A metal tag will be applied at the base of the boundary level.

Completeness of the section: The Alano section contains excellent and continuous faunal/floral and magnetic polarity records across the Bartonian to Priabonian transition. All the reference biostratigraphic and magnetostratigraphic events are present. If hiatuses occur, their durations are below the resolution provided by bio-magnetostratigraphic datums. An average sediment accumulation rate of $\sim 2.4 \mathrm{~cm} / \mathrm{kyr}$ (not corrected for compaction) was estimated assuming constant sediment accumulation rates between magnetochron boundaries (Agnini et al., 2011).

Global correlation: The global correlation of the Priabonian GSSP is assured by different events, applicable in marine and continental stratigraphic records over large areas and depositional settings. The Base of Subchron C17n.3n (52.62 m level) is located $10.95 \mathrm{~m}$ below the proposed GSSP and serves as a good approximation of the base of the Priabonian in continental and marine settings. The floating chronology available for the Alano section indicates that this event precedes the Priabonian GSSP by 290 kyr (Fig. 3; Galeotti et al., 2019). Though the Base of Chron $\mathrm{C} 17 \mathrm{n}$ has surely the highest correlation potential among the polarity reversals across the critical interval, the closest magnetostratigraphic boundary is the Base of Subchron C17n.2n (62.48 m level), which is positioned $1.09 \mathrm{~m}$ below the Tiziano Bed preceding the base of the Priabonian by $30 \mathrm{kyr}$ (Fig. 3; Galeotti et al., 2019). Based on precession cycle counting the base of the Tiziano bed lies at $\sim 12 \%$ of Subchron C17n.2n.

In Fig. 3 (and Table 1) the age of the Tiziano bed, that is the base of the Priabonian, is compared with biochronologic data based on calcareous plankton, the most powerful correlation tool available in Cenozoic marine sediments. The extinction of the large acarininids and Morozovelloides approximates the base of the Priabonian within 170-173 kyr (Fig. 3; Galeotti et al., 2019). The Base of calcareous nannofossil C. oamaruensis should be used with extreme caution because this taxon is exceedingly rare at low to middle latitudes (Fornaciari et al., 2010). However, two highly reliable calcareous nannofossil biohorizons, the Base of common and continuous C. erbae (62.92 m level; $-20 \mathrm{kyr}$ ) and the $\mathrm{T}$ of $C$. grandis ( $66.47 \mathrm{~m}$ level; $+22 \mathrm{kyr}$ ) are recorded close to the Tiziano bed (Fig. 3; Table 1). These biohorizons were tested outside the GSSP section to evaluate their reproducibility. The same ranking and spacing was observed when several on-land and oceanic successions were compared (Fornaciari et al., 2010; Agnini et al., 2011). The proposed definition of the GSSP of the Priabonian will serve to overcome the present state of uncertainty in recognizing the Bartonian/Priabonian boundary.

Previous votes: During the Priabonian Working Group meeting held in 2012 in Alano (Italy), the Alano section was elected as a suitable candidate for the Priabonian GSSP with an unanimous decision adopted by the Priabonian Working Group, which also voted in favor of the Tiziano bed, as the formal definition of the Priabonian GSSP (see Appendices 1,2 for details).

The International Subcommision on Paleogene Stratigraphy (ISPS) and the International Commission on Stratigraphy (ICS) approved the Priabonian GSSP proposal on August $28^{\text {th }} 2019$ and January $17^{\text {th }} 2020$, respectively. The IUGS Executive unanimously ratified the Eocene Priabonian Stage GSSP on February $17^{\text {th }} 2020$.

\section{Acknowledgements}

We would like to thank all the people who have been involved in various capacities in the long process of defining the base of the Priabonian Stage. We greatly acknowledge the Paleogene community who has stimulated fruitful discussions on stratigraphy and chronostratigraphy of the Bartonian-Priabonian interval during the Priabonian Working Group meetings as well as the ISPS/ICS/IUGS assemblies.

\section{References}

Agnini, C., Muttoni, G., Kent, D.V., and Rio, D., 2006, Eocene biostratigraphy and magnetic stratigraphy from Possagno, Italy: The calcareous nannofossil response to climate variability. Earth and Planetary Science Letters, v. 241, pp. 815-830.

Agnini, C., Fornaciari, E., Giusberti, L., Grandesso, P., Lanci, L., Luciani, V., Muttoni. G., Pälike, H., Rio, D., Spofforth, D.J.A., and Stefani, C., 2011. Integrated bio-magnetostratigraphy of the Alano section (NE Italy): a proposal for defining the Middle-Late Eocene boundary. Geological Society of America Bulletin, v. 123, pp. 841-872.

Agnini, C., Fornaciari, E., Raffi, I., Catanzariti, R., Pälike, H., Backman, J., and Rio, D., 2014, Biozonation and biochronology of Paleogene calcareous nannofossils from low and middle latitudes. Newsletters on Stratigraphy, v. 47, pp. 131-181.

Bassi, D., and Loriga Broglio, C., 1999, Alveolinids at the middle-upper Eocene boundary in northeastern Italy (Veneto, Colli Berici, Vicenza). Journal of Foraminiferal Research, v. 29, pp. 222-235.

Berggren, W.A. and Miller, K.G., 1989, Cenozoic bathyal and abyssal calcareous benthic foraminiferal zonation. Micropaleontology, v. 35, pp. 308-320.

Berggren, W.A., and Pearson, P.N., 2005, A revised tropical to subtropical Paleogene planktonic foraminiferal zonation: Journal of Foraminiferal Research, v. 35, pp. 279-298.

Berggren, W.A., Kent, D.V., Flynn, J.J., and Van Couvering, J.A., 1985, Cenozoic geochronology: Geological Society of America Bulletin, v. 96, pp. 1407-1418.

Berggren, W.A., Kent, D.V., Swisher, C.C., III, and Aubry, M.-P., 1995, A revised Cenozoic geochronology and chronostratigraphy. In: Berggren, W.A., et al. (Eds.), Geochronology, Time Scales and Global Stratigraphic Correlation. Society for Sedimentary Geology Special Publication, 54, pp. 129-212.

Bernoulli, D., 1972, North Atlantic and Mediterranean Mesozoic facies: A 
comparison. In: Hollister, C.D., Ewing, J.I., et al. (Eds.)., Proceedings of Deep Sea Drilling Project, Initial Reports, v. 11,pp. 301-871.

Bohaty, S.M., and Zachos, J.C., 2003, Significant Southern Ocean warming event in the late middle Eocene. Geology, v. 31, pp. 1017-1020.

Bohaty, S.M., Zachos, J.C., Florindo, F., Delaney, M.L., 2009, Coupled greenhouse warming and deep-sea acidification in the middle Eocene. Paleoceanography, v. 24, PA2207.

Bolli, H.M., (Ed.), 1975, Monografia micropaleontologica sul Paleocene e l'Eocene di Possagno, Provincia di Treviso, Italia. Schweizerische Palaeontologische Abhandlungen, $222 \mathrm{p}$.

Boscolo-Galazzo, F., Giusberti, L., Luciani, V., and Thomas, E., 2013, Paleoenvironmental changes during the Middle Eocene Climatic Optimum (MECO) and its aftermath: The benthic foraminiferal record from the Alano section (NE Italy). Palaeogeography, Palaeoclimatology, Palaeoecology, v. 378, pp. 22-35.

Boscolo-Galazzo, F., Thomas, E., Luciani, V., Giusberti, L., Frontalini, F., and Coccioni, R., 2016, The planktic foraminifer Planorotalites in the Tethyan middle Eocene. Journal of Micropalaeontology, v. 35, pp.7989.

Bosellini, A., 1989, Dynamics of Tethyan carbonate platform. In: Crevello, P.D., et al., (Eds.), Controls on Carbonate Platform and Basin Platform. Society for Sedimentary Geology Special Publication, v. 44, pp. $3-13$.

Bosellini, F.R., and Papazzoni, C.A., 2003, Palaeoecological significance of coral-encrusting foraminiferan associations. A case-study from the Upper Eocene of northern Italy. Acta Palaeontologica Polonica, v. 48, pp. 279-292.

Brinkhuis, H., 1994, Late Eocene to early Oligocene dinoflagellate cysts from the Priabonian type-area (northeast Italy): Biostratigraphy and paleoenvironmental interpretation. Palaeogeography, Palaeoclimatology, Palaeoecology, v. 107, pp. 121-163.

Cande, S.C., and Kent, D.V., 1995, Revised calibration of the geomagnetic polarity time scale for the Late Cretaceous and Cenozoic. Journal of Geophysical Research, v. 100, B4, pp. 6093-6096.

Cita, M.B., 1969, Le Paleocene et l'Eocene de l'Italie du nord, in Colloque sur l'Eocene, Paris (1968), France. Mémoires du Bureau des Recherches Géologiques et Minières, v. 69, pp. 417-428.

Cita, M.B., 1975, Stratigrafia della Sezione di Possagno, In: Bolli, H.M., (Ed.), Monografia Micropaleontologica sul Paléocene e l'Eocéne di Possagno, Provincia di Treviso, Italia. Schweizerische Palaeontologische Abhandlungen, v. 97, pp. 9-33.

Cotton, L., Zakrevskaya, E.Y., Boon, A. van der, Asatryan, G., Hayrapetyan, F., Israelyan, A., Krijgsman, W., Less, G., Monechi, S., Papazzoni, C.A., Pearson, P.N., Razumovskiy, A., Renema, W., Shcherbinina, E., and Wade B.S., 2017, Integrated stratigraphy of the Priabonian (upper Eocene) Urtsadzor section, Armenia. Newsletters on Stratigraphy, v. 50, pp. 269-295.

Cowie, J.W., Ziegler, W., Boucot, A.J., Bassett, M.G., and Remane, J., 1986, Guidelines and statutes of the International Commission on Stratigraphy (ICS). Courier Forschungs-Institut Senckenberg, v. 83, pp. 114.

de Lapparent, A., 1893. Traité de Géologie. 3e. éd. viii + 1645 pp. Librairie F. Savy, Paris.

Doglioni, C., and Bosellini, A., 1987, Eoalpine and Mesoalpine tectonics in the southern Alps. Geologische Rundschau, v. 76, pp. 735-754.

Fornaciari, E., Agnini, C., Catanzariti, R., Rio, D., Bolla, E.M., and Valvasoni, E., 2010, Mid-latitude calcareous nannofossil biostratigraphy and biochronology across the middle to late Eocene transition. Stratigraphy, v. 7, pp. 229-264.

Galeotti, S., Sahy, D., Agnini, C., Condon, D., Fornaciari, E., Francescone, F., Giusberti, L., Pälike, H., Spofforth, D.J.A., and Rio, D., 2019, Astrochronology and radio-isotopic dating of the Alano di Piave section (NE Italy), candidate GSSP for the Priabonian Stage. Earth and Planetary Science Letters, v. 525, pp. 115746.

Hardenbol, J., 1968, The "Priabonian" type section (a preliminary note).
Mémoires du Bureau des Recherches Géologiques et Minières, v. 58, pp. 629-635.

Hedberg, H.D., (Ed.), 1976, International Stratigraphic Guide: New York, John Wiley and Sons, $200 \mathrm{p}$.

Hottinger, L., 1977, Foraminifêres operculiniformes. Mémoires du Muséum National d'Histoire Naturelle, v. 40, pp.1-159.

Luciani, V., Negri, A., and Bassi, D., 2002, The Bartonian-Priabonian transition in the Mossano section (Colli Berici, north-eastern Italy): A tentative correlation between calcareous plankton and shallow-water benthic zonations. Geobios, v. 35, pp. 140-149.

Luciani, V., Giusberti, L., Agnini, C., Fornaciari, E., Rio, D., Spofforth, D.J.A., and Pälike, H., 2010, Ecological and evolutionary response of Tethyan planktonic foraminifera to the middle Eocene climatic optimum (MECO) from the Alano section (NE Italy). Palaeogeography, Palaeoclimatology, Palaeoecology, v. 292, pp. 82-95.

Luciani, V., Fornaciari, E., Papazzoni, C.A., Dallanave, E., Giusberti, L., Stefani, C., and Amante, E., 2020, Integrated stratigraphy at the Bartonian-Priabonian transition: correlation between shallow benthic and calcareous plankton zones (Varignano section, northern Italy). Geological Society of America Bulletin, v. 132, pp. 495-520.

Luterbacher, H.P., Ali, J.R., Brinkhuis, H., Gradstein, F.M., Hooker, J.J., Monechi, S., Ogg, J.G., Powell, J., Röhl, U., Sanfilippo, A., and Schmitz, B., 2004, The Paleogene Period. In: Gradstein, F.M., et al. (Eds.), A Geological Time Scale: Cambridge, UK, Cambridge University Press, pp. 384-408.

Martini, E., 1971, Standard Tertiary and Quaternary calcareous nannoplankton zonation. In: Farinacci, A., (Ed.), Proceedings of the 2nd Planktonic Conference, Rome, Tecnoscienza, v. 2, pp. 739-785.

Munier-Chalmas, E., and de Lapparent, A., 1894, Note sur la nomenclature des terrains sédimentaires. Bulletin de la Société Géologique de France, v. 21, pp. 438-488.

Okada, H., and Bukry, D., 1980, Supplementary modification and introduction of code numbers to the low latitude coccolith biostratigraphic zonation (Bukry, 1973; 1975). Marine Micropaleontology, v. 5, pp. 321-325.

Payros, A., Dinarès-Turell, J., Monechi, S., Orue-Etxebarria, X., Ortiz, S., Apellaniz, E., and Martínez-Braceras, N., 2015, The Lutetian/Bartonian transition (middle Eocene) at the Oyambre section (northern Spain): Implications for standard chronostratigraphy. Palaeogeography, Palaeoclimatology, Palaeoecology, v. 440, pp. 234-248.

Papazzoni, C.A., and Sirotti, A., 1995, Nummulite biostratigraphy at the Middle/Upper Eocene boundary in the northern Mediterranean area. Rivista Italiana di Paleontologia e Stratigrafia, v. 101, pp. 63-80.

Papazzoni, C.A., Moretti, A., Luciani, V., Fornaciari, E., and Giusberti, L., 2014, The Varignano section (Trento Province, northern Italy): A chance to correlate shallow benthic zones and calcareous plankton zones near the Bartonian-Priabonian boundary. Rendiconti Online della Società Geologica Italiana, v. 31, pp. 165-166.

Pälike, H., Shackleton, N.J., and Röhl, U., 2001, Astronomical forcing in late Eocene marine sediments. Earth and Planetary Science Letters, v. 193, pp. 589-602.

Pälike, H., Norris, R.D., Herrle, J.O., Wilson, P.A., Coxall, H.K., Lear, C.H., Shackleton, N.J., Tripati, A.K., and Wade, B.S., 2006, The heartbeat of the Oligocene climate system. Science, v. 314, pp. 1894-1898.

Parisi, G., Guerrera, G., Madile, F., Magnoni, M., Monaco, P., Monechi, S., and Nocchi, M., 1988. Middle Eocene to early Oligocene calcareous nannofossil and foraminiferal biostratigraphy in the Monte Cagnero section, Piobbico (Italy). In Premoli Silva, I., et al., (Eds.), The EoceneOligocene Boundary in the Marche-Umbria Basin (Italy): Ancona, Italy, Fratelli Anniballi, International Union of Geological Sciences Special Publication, International Subcommission on Paleogene Stratigraphy Report, p. 119-136.

Pearson, P.N., Wade, B.S., Backman, J., Raffi, I., and Monechi, S., 2017, Sub-series and sub-epochs are informal units and should continue to be omitted from the International Chronostratigraphic Chart. Episodes, v. 
40 , pp. 5-7.

Perch-Nielsen, K., 1985, Cenozoic calcareous nannofossils. In: Bolli, H.M., Saunders, J.B., and Perch-Nielsen, K., (Eds.), Plankton Stratigraphy: Cambridge, UK, Cambridge University Press, pp. 427-554.

Remane, J., Bassett, M.G., Cowie, J.W., Gohrbandt, K.H., Lane, H.R., Michelsen, O., and Naiwen, W., 1996, Revised guidelines for the establishment of global chronostratigraphic standards by the International Commission on Stratigraphy (ICS). Episodes, v. 19, pp 77-81.

Remane, J., 2003, Chronostratigraphic correlations: Their importance for the definition of geochronologic units. Palaeogeography, Palaeoclimatology, Palaeoecology, v. 196, pp. 7-18.

Rodelli, D., Jovane, L., Özcan, E., Giorgioni, M., Coccioni, R., Frontalini, F., Rego, E.S., Brogi, A., Catanzariti, R., Less, G., and Rostami, M.A., 2018, High-resolution integrated magnetobiostratigraphy of a new middle Eocene section from the Neotethys (Elazig Basin, eastern Turkey). Geological Society of America Bulletin, v. 130, pp. 193-207.

Serra-Kiel, J., Hottinger, L., Caus, E., Drobne, K., Ferràndez, C., Jauhri, A.K., Less, G., Pavlovec, R., Pignatti, J., Samsó, J.M., Schaub, H., Sirel, E., Strougo, A., Tambareau, Y., Tosquella, J., and Zakrevskaya, E., 1998, Larger foraminiferal biostratigraphy of the Tethyan Paleocene and Eocene. Bulletin de la Société Géologique de France, v. 169, pp. 281299

Setiawan, J.R., 1983, Foraminifera and microfacies of the type Priabonian. Utrecht Micropaleontological Bulletins, v. 29, 173 p.

Spofforth, D.J.A., Agnini, C., Pälike, H., Rio, D., Bohaty, S., Fornaciari, E., Giusberti, L., Lanci, L., Luciani, V., and Muttoni, G., 2010, Organic Carbon Burial following the Middle Eocene Climatic Optimum (MECO) in the central-western Tethys. Paleoceanography, v. 25, PA3210.

Strougo, A., 1992, The Middle Eocene/Upper Eocene transition in Egypt reconsidered. Neues Jahrbuch für Geologie und Paläontologie Abhandlungen, v. 186, pp. 71-89.

Toffanin, F., Agnini, C., Fornaciari, E., Rio, D., Giusberti, L., Luciani, V., Spofforth, D.J.A., and Pälike, H., 2011, Changes in calcareous nannofossil assemblages during the Middle Eocene Climatic Optimum: clues from the central-western Tethys (Alano section, NE Italy). Marine Micropal- eontology, v. 81, pp. 22-31.

Trevisani, E., 1997, Stratigrafia sequenziale e paleogeografia del margine orientale del Lessini Shelf durante l'Eocene superiore (Prealpi Venete, provincie di Vicenza e Treviso). Studi Trentini di Scienze Naturali, Acta Geologica, v. 71, pp. 145-168.

Vandenberghe, N., Hilgen, F.J., Speijer, R.P., Ogg, J.G., Gradstein, F.M., Hammer, O., and Hooker, J.J., 2012, The Paleogene period. In: Gradstein, F.M et al. (Eds.), The Geological Time Scale 2012: Amsterdam, Elsevier, Netherlands (2012), pp. 855-921.

Verhallen, P.J.J.M., and Romein, A.J.T., 1983, Calcareous nannofossils from Priabonian stratotype and correlation with the parastratotype, In: Setiawan, J.R, (Ed.), Foraminifers and Microfacies of the Type-Priabonian. Utrecht Micropaleontological Bulletins, v. 29, pp. 163-173.

Wade, B.S., 2004, Planktonic foraminiferal biostratigraphy and mechanisms in the extinction of Morozovella in the late middle Eocene: Marine Micropaleontology, v. 51, pp. 23-38.

Wade, B.S., Pearson, P.N., Berggren, W.A., and Pälike, H., 2011, Review and revision of Cenozoic tropical planktonic foraminiferal biostratigraphy and calibration to the geomagnetic polarity and astronomical time scale. Earth-Science Reviews, v. 104, pp. 111-142.

Wade, B.S., Fucek, V.P., Kamikuri, S.I., Bartol, M., Luciani, V., and Pearson, P.N., 2012, Successive extinctions of muricate planktonic foraminifera (Morozovelloides and Acarinina) as a candidate for marking the base Priabonian. Newsletters on Stratigraphy, v. 45, pp. 245-262.

Wei, W., and Wise Jr., S.W., 1989, Paleogene calcareous nannofossil magnetobiostratigraphy: results from South Atlantic DSDP 516. Marine Micropaleontology, v. 14, pp. 119-152.

Westerhold, T., Röhl, U., Pälike, H., Wilkens, R., Wilson, P.A., and Acton, G., 2014, Orbitally tuned timescale and astronomical forcing in the middle Eocene to early Oligocene. Climate of the Past, v. 10, pp. 955973.

Winterer, E.L., and Bosellini, A., 1981, Subsidence and sedimentation on Jurassic passive continental margin, southern Alps, Italy. The American Association of Petroleum Geologists Bulletin, v. 65, pp. 394-421. 


\section{Appendices}

Appendix 1. Composition of the Alano Working Group

\begin{tabular}{|c|c|c|c|c|}
\hline & Name & e-mail & Affiliation & Expertise \\
\hline 1 & Agnini Claudia & claudia.agnini@unipd.it & University of Padova (Italy) & calcareous nannofossils \\
\hline 2 & Alegret Laia & laia@unizar.es & Zaragoza University (Spain) & small benthic foraminifera \\
\hline 3 & Arenillas Ignacio & ias@unizar.es & Zaragoza University (Spain) & planktonic foraminifera \\
\hline 4 & Backman Jan & backman@geo.su.se & Stockholm University (Sweden) & calcareous nannofossils \\
\hline 5 & Balini Marco & marco.balini@unimi.it & University of Milan (Italy) & biostratigraphy \\
\hline 6 & Fornaciari Eliana & eliana.fornaciari@unipd.it & University of Padova (Italy) & calcareous nannofossils \\
\hline 7 & Galeotti Simone & simone.galeotti@uniurb.it & University of Urbino "Carlo Bo" (Italy) & cyclostratigraphy \\
\hline 8 & Giusberti Luca & luca.giusberti@unipd.it & University of Padova (Italy) & Small benthic foraminifera \\
\hline 9 & Grandesso Paolo & paolo.grandesso@libero.it & University of Padova (Italy) & stratigraphy \\
\hline 10 & Lanci Luca & luca.lanci@uniurb.it & University of Urbino "Carlo Bo" (Italy) & magnetostratigraphy \\
\hline 11 & Luciani Valeria & valeria.luciani@unife.it & Ferrara University (Italy) & planktonic foraminifera \\
\hline 12 & Mietto Paolo & paolo.mietto@unipd.it & University of Padova (Italy) & stratigraphy \\
\hline 13 & Molina Eustoquio ${ }^{\dagger}$ & emolina@unizar.es & Zaragoza University (Spain) & planktonic foraminifera \\
\hline 14 & Monechi Simonetta & simonetta.monechi@unifi.it & Univerisity of Florence (Italy) & calcareous nannofossils \\
\hline 15 & Muttoni Giovanni & giovanni.muttoni1@unimi.it & University of Milan (Italy) & magnetostratigraphy \\
\hline 16 & Pälike Heiko & hpaelike@marum.de & Bremen University (Germany) & cyclostratigraphy \\
\hline 17 & Pampaloni Maria Letizia & marialetizia.pampaloni@isprambiente.it & ISPRA Roma (Italy) & biostratigraphy \\
\hline 18 & Papazzoni Cesare A. & cesareandrea.papazzoni@unimore.it & University of Modena and Reggio Emilia (Italy) & larger benthic foraminifera \\
\hline 19 & Pearson Paul & PearsonP@cardiff.ac.uk & Cardiff University (United Kingdom) & planktonic foraminifera \\
\hline 20 & Pichezzi Rita & rita.pichezzi@isprambiente.it & ISPRA Roma (Italy) & biostratigraphy \\
\hline 21 & Pignatti Johannes & johannes.pignatti@uniroma1.it & University of Rome "La Sapienza" (Italy) & larger benthic foraminifera \\
\hline 22 & Premoli Silva Isabella & isabella.premoli@unimi.it & University of Milan (Italy) & planktonic foraminifera \\
\hline 23 & Raffi Isabella & raffi@unich.it & $\begin{array}{l}\text { "Gabriele d'Annunzio" University of } \\
\text { Chieti-Pescara (Italy) }\end{array}$ & calcareous nannofossils \\
\hline 24 & Rio Domenico & domenico.rio@unipd.it & University of Padova (Italy) & calcareous nannofossils \\
\hline 25 & Rook Lorenzo & lorenzo.rook@unifi.it & Univerisity of Florence (Italy) & vertebrate paleontology \\
\hline 26 & Stefani Cristina & cristina.stefani@unipd.it & University of Padova (Italy) & sedimentology \\
\hline 27 & Wade Bridget & b.wade@ucl.ac.uk & University College London (United Kingdom) & planktonic foraminifera \\
\hline
\end{tabular}

Appendix 2. Results of the ballots* of the working group

\begin{tabular}{|c|c|c|c|c|c|c|c|}
\hline $\begin{array}{l}\text { 1) Is the Alano section the best candidate for defining the Priabonian } \\
\text { GSSP? Alano meeting (June 9-10, 2012). Please corfirm your vote. }\end{array}$ & $\begin{array}{c}\begin{array}{c}\text { Alano voting } \\
\text { members }\end{array} \\
\end{array}$ & ABSENT & $\begin{array}{l}\text { TOTAL } \\
\text { voters }\end{array}$ & $\begin{array}{c}\mathrm{IN} \\
\text { FAVOR }\end{array}$ & AGAINST & NULL & ABSTAIN \\
\hline & 27 & 3 & 24 & 23 & 0 & 0 & 1 \\
\hline voter percentage $(\%)$ & 88.9 & & & & & & \\
\hline results $(\%)$ & & & & 95.8 & 0.0 & 0.0 & 4.2 \\
\hline
\end{tabular}

2) Is the Tiziano bed the best definition for the Priabonian GSSP?

Alano meeting (June 9-10, 2012). Please corfirm your vote.

\begin{tabular}{|c|c|c|c|c|c|c|c|}
\hline & 27 & 3 & 24 & 19 & 4 & 0 & 1 \\
\hline voter percentage $(\%)$ & 88.9 & & & & & & \\
\hline results $(\%)$ & & & & 79.2 & 16.7 & 0.0 & 4.2 \\
\hline \multirow[t]{2}{*}{$\begin{array}{l}\text { 3) Is the Alano section the best candidate for defining the Pria- } \\
\text { bonian GSSP? Present ballot (to vote by July 10, 2015) }\end{array}$} & $\begin{array}{l}\text { Alano voting } \\
\text { members }\end{array}$ & $\begin{array}{c}\text { NOT } \\
\text { VOTING }\end{array}$ & $\begin{array}{l}\text { TOTAL } \\
\text { voters }\end{array}$ & $\begin{array}{c}\mathrm{IN} \\
\text { FAVOR }\end{array}$ & AGAINST & NULL & ABSTAIN \\
\hline & 27 & 2 & 25 & 25 & 0 & 0 & 0 \\
\hline voter percentage $(\%)$ & 92.6 & & & & & & \\
\hline results (\%) & & & & 100.0 & 0.0 & 0.0 & 0.0 \\
\hline
\end{tabular}

4) Is the Tiziano bed the best definition for the Priabonian GSSP?

Present ballot (to vote by July 10, 2015)

voter percentage $(\%)$

$\begin{array}{ccccccc}27 & 2 & 25 & 20 & 4 & 0 & 1 \\ 92.6 & & & & & & \\ & & & 80.0 & 16.0 & 0.0 & 4.0\end{array}$

results (\%)

$\begin{array}{llll}80.0 & 16.0 & 0.0 & 4.0\end{array}$

*The ballot was repeated in 2015 to give all the members of the working group the chance to vote, in fact in 2012 not all the members were present in Alano di Piave during the meeting. 


\section{Plates}
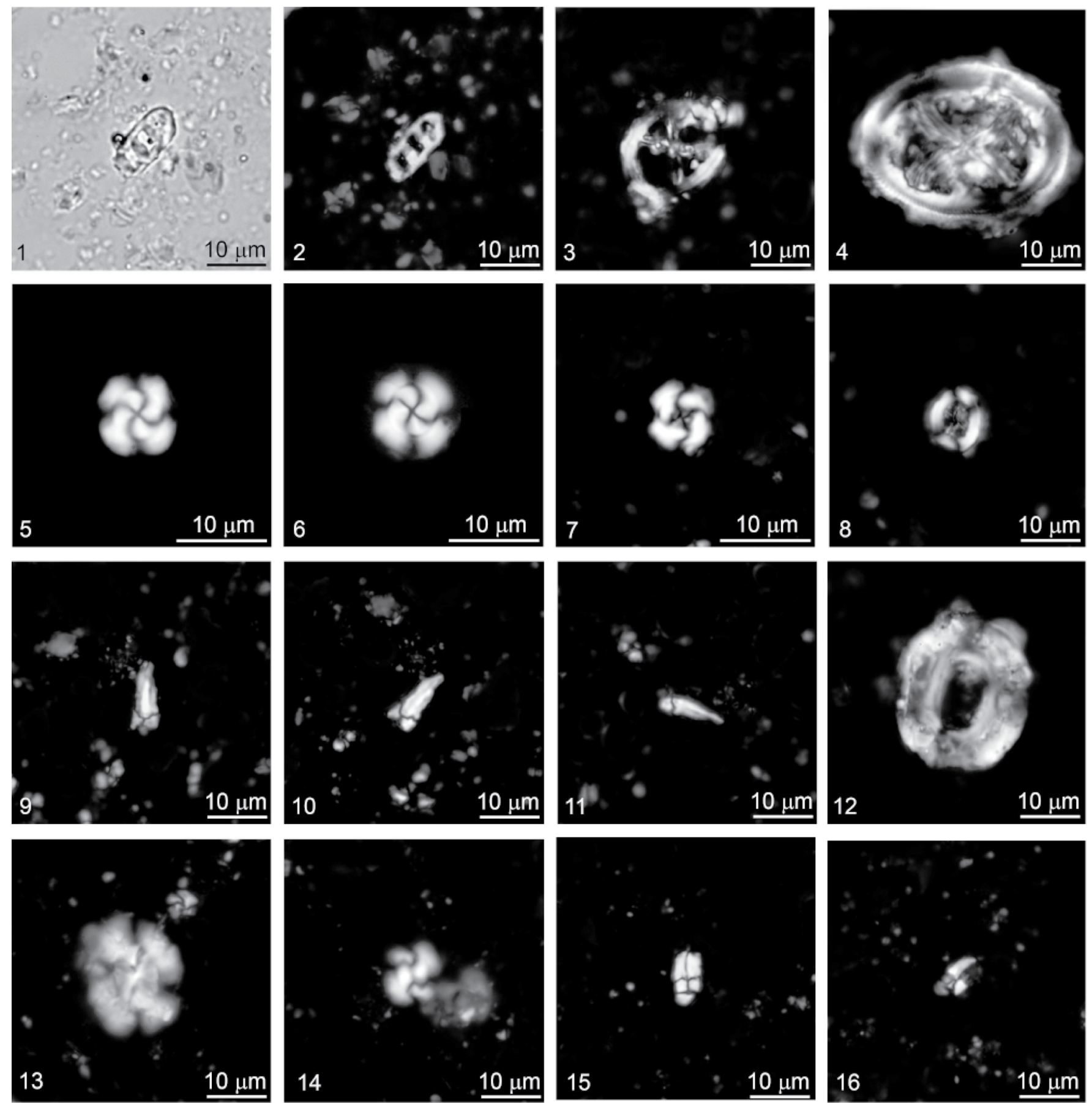

Plate I. (after Agnini et al., 2011). Microphotographs of selected calcareous nannofossil taxa from the Bartonian-Priabonian Alano section (northern Italy). 1, 2 - Isthmolithus recurvus. Sample COL 4645c (1. parallel light; 2. crossed nicols). 3 - Chiasmolithus oamaurensis. Sample COL 5225c. Crossed nicols. 4 - Chiasmolithus grandis. Sample COL 40a. Crossed nicols. 5, 6 - Cribrocentrum erbae (5. sample COL 3521c, crossed nicols; 6. sample $171 \mathrm{~B}-1052 \mathrm{~B}-10 \mathrm{H}-2 \mathrm{w}, 130 \mathrm{~cm}$, crossed nicols). 7 - Cribrocentrum reticulatum. Sample COL $10 b$. Crossed nicols. 8 - Chiasmolithus solitus. Sample COL 40a. Crossed nicols. 9-11 - Sphenolithus obtusus. Sample COL 1285b (9. crossed nicols $0^{\circ}$; 10. crossed nicols $45^{\circ}$; 11. crossed nicols $20^{\circ}$ ). 12 - Reticulofenestra umbilicus. Sample COL 40a. Crossed nicols. 13 - Dictyococcites bisectus. Sample COL 40a. Crossed nicols. 14 - Dictyococcites hesslandii. Sample COL 40a. Crossed nicols. 15, 16 - Sphenolithus furcatolithoides. Sample COL O (15. crossed nicols $0^{\circ}$; 16. crossed nicols $45^{\circ}$ ). 


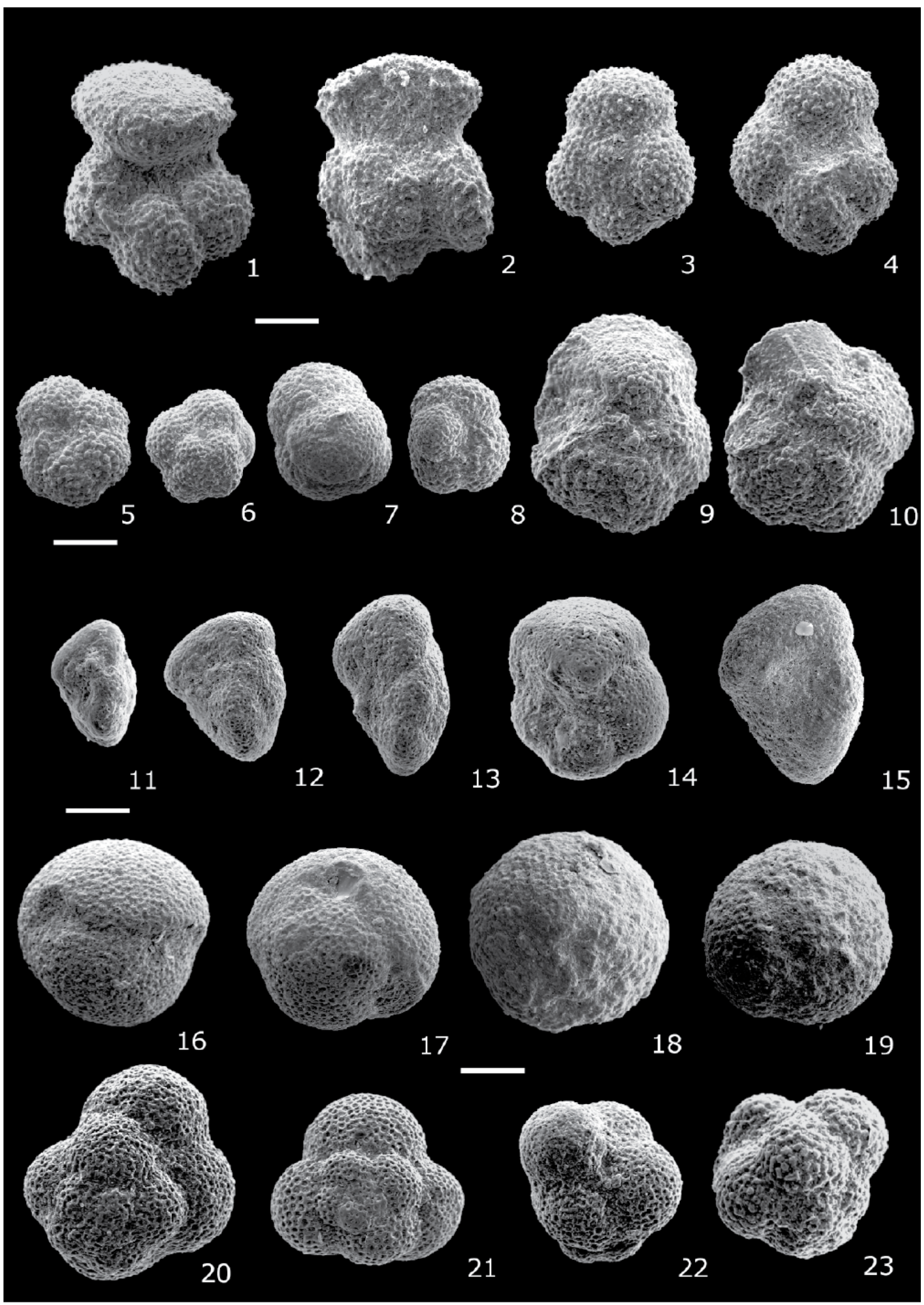

Plate II. (after Agnini et al., 2011)1-23: Planktonic foraminiferal scanning electron micrograph (SEM) images of selected zonal markers from the Bartonian-Priabonian Alano section (northern Italy). large acarininids: 1, 2-Acarinina topilensis. Sample COL 345 b (1. ventral view; 2. spiral view). 3, 4-Acarinina rohri (3. sample COL 40a, spiral view; 4. sample COL 600a, spiral view). Small acarininids: 5, 6 Acarinina medizzai. Sample COL 2799c (5. ventral view; 6. spiral view). 7, 8-Acarinina echinata. Sample COL 4845c (7. ventral view; 8. ventral view). 9 - Morozovelloides coronatus. Sample COL 2496c, ventral view. 10 - Morozovelloides crassatus. Sample COL 732 , ventral view. 11-15 - Turborotalia cocoaensis (11, 12, 13-sample COL 520a [horizon of lowest occurrence of the species], profi le; 14. sample COL 600 a, ventral view; 15 - sample COL 1285b, profile). 16, 17-Globigerinatheka semiinvoluta. Sample COL 4605c. 18, 19 - Orbulinoides beckmanni. Sample COL 440a. 20-23 - Guembelitroides nuttalli (20. sample COL 240a, spiral side; 21. sample COL 3701c, spiral side; 22. sample COL 492c, ventral side; 23 - sample COL 3281c, lateral side). Scale bar $=100 \mu m$. 